PNL-2833

UC-20e

\title{
Environmental Consequences of Postulated Plutonium Releases from the Babcock \& Wilcox Plant, Leechburg, Pennsylvania, as a Result of Severe Natural Phenomena
}

March 1979

Prepared for

Division of Environmental Impact Studies

Argonne National Laboratory under a Related Services Agreement with the U.S. Department of Energy

Contract EY-76-C-06-1830

Pacific Northwest Laboratory Operated for the U.S. Department of Energy by Battelle Memorial Institute 


\title{
NOTICE
}

This report was prepared as an account of work sponsored by the United States Government. Neither the United States nor the Department of Energy, nor any of their employees, nor any of their contractors, subcontractors, or their employees, makes any warranty, express or implied, or assumes any legal liability or responsibility for the accuracy, completeness or usefulness of any information, apparatus, product or process disclosed, or represents that its use would not infringe privately owned rights.

The views, opinions and conclusions contained in this report are those of the contractor and do not necessarily represent those of the United States Government or the United States Department of Energy.

\author{
PACIFIC NORTHWEST LABORATORY \\ operated by \\ BATTELLE \\ for the \\ UNITED STATES DEPARTMENT OF ENERGY \\ Under Contract EY-76-C-06-1830
}

\begin{tabular}{|c|c|}
\hline \multicolumn{2}{|c|}{$\begin{array}{l}\text { Printed in the United States of America } \\
\text { Available from } \\
\text { National Technical Information Service } \\
\text { United States Department of Commerce } \\
5285 \text { Port Royal Road } \\
\text { Springfield, Virginia } 22151\end{array}$} \\
\hline e: Printed Copy & - Microfiche $\$ 3.0$ \\
\hline -Pages & $\begin{array}{l}\text { NTIS } \\
\text { Selling Price }\end{array}$ \\
\hline $001-025$ & $\$ 4.00$ \\
\hline $026-050$ & $\$ 4.50$ \\
\hline $051-075$ & $\$ 5.25$ \\
\hline $076-100$ & $\$ 6.00$ \\
\hline $101-125$ & $\$ 6.50$ \\
\hline $126-150$ & $\$ 7.25$ \\
\hline $151-175$ & $\$ 8.00$ \\
\hline $176-200$ & $\$ 9.00$ \\
\hline $201-225$ & $\$ 9.25$ \\
\hline $226-250$ & $\$ 9.50$ \\
\hline $251-275$ & $\$ 10.75$ \\
\hline $276-300$ & $\$ 11.00$ \\
\hline
\end{tabular}


PNL -2833

UC-20e

\section{1}

ENVIRONMENTAL CONSEQUENCES OF POSTULATED PLUTONIUM RELEASES FROM THE BABCOCK AND WILCOX PLANT, LEECHBURG, PENNSYLVANIA, AS A RESULT OF SEVERE NATURAL PHENOMENA

R. B. McPherson

E. C. Watson

March 1979

Prepared for

Division of Environmental Impact Studies

Argonne National Laboratory under a Related Services Agreement with the U.S. Department of Energy

Contract EY-76-C-06-1830

Pacific Northwest Laboratory

Richland, Washington 99352 

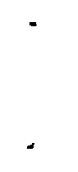

$\because$ 


\section{SUMMARY}

Potential environmental consequences in terms of radiation dose to people are presented for postulated plutonium releases accidently caused by severe natural phenomena at the Babcock and Wilcox plant, Leechburg, Pennsyivania. The severe natural phenomena considered are earthquakes, tornadoes, high straight-line winds, and floods. Maximum plutonium deposition values are given for significant locations around the site. All important potential exposure pathways are examined. The most 1 ikely 50-year committed dose equivalents are given in Table 1 for the maximum-exposed individual and the population within a 50-mile radius of the plant. The maximum plutonium deposition values most likely to occur at the site boundary are also given in Table 1.

The most likely calculated 50-year collective committed dose equivalents are all much lower than the collective dose equivalent expected from 50 years of exposure to natural background radiation and medical x-rays. The most likely maximum residual plutonium contamination estimated to be deposited at the site boundary following Earthquake No. 3, the 110-mph and 130-mph winds, and the $130 \mathrm{mph}$ tornado are above the Environmental Protection Agency's (EPA) proposed guideline for plutonium in the general environment of $0.2 \mathrm{\mu} \mathrm{i} / \mathrm{m}^{2}$. At distances of 600 meters from the plant, where the closest farm is located, the most likely contamination levels are estimated to be closer to the EPA's proposed guideline. For the second earthquake event and the 85- and 95-mph winds, the deposition values are below the EPA proposed guideline. 
TABLE 1. Most Likely 50-Year Committed Dose Equivalents and Maximum Plutonium Deposition Values

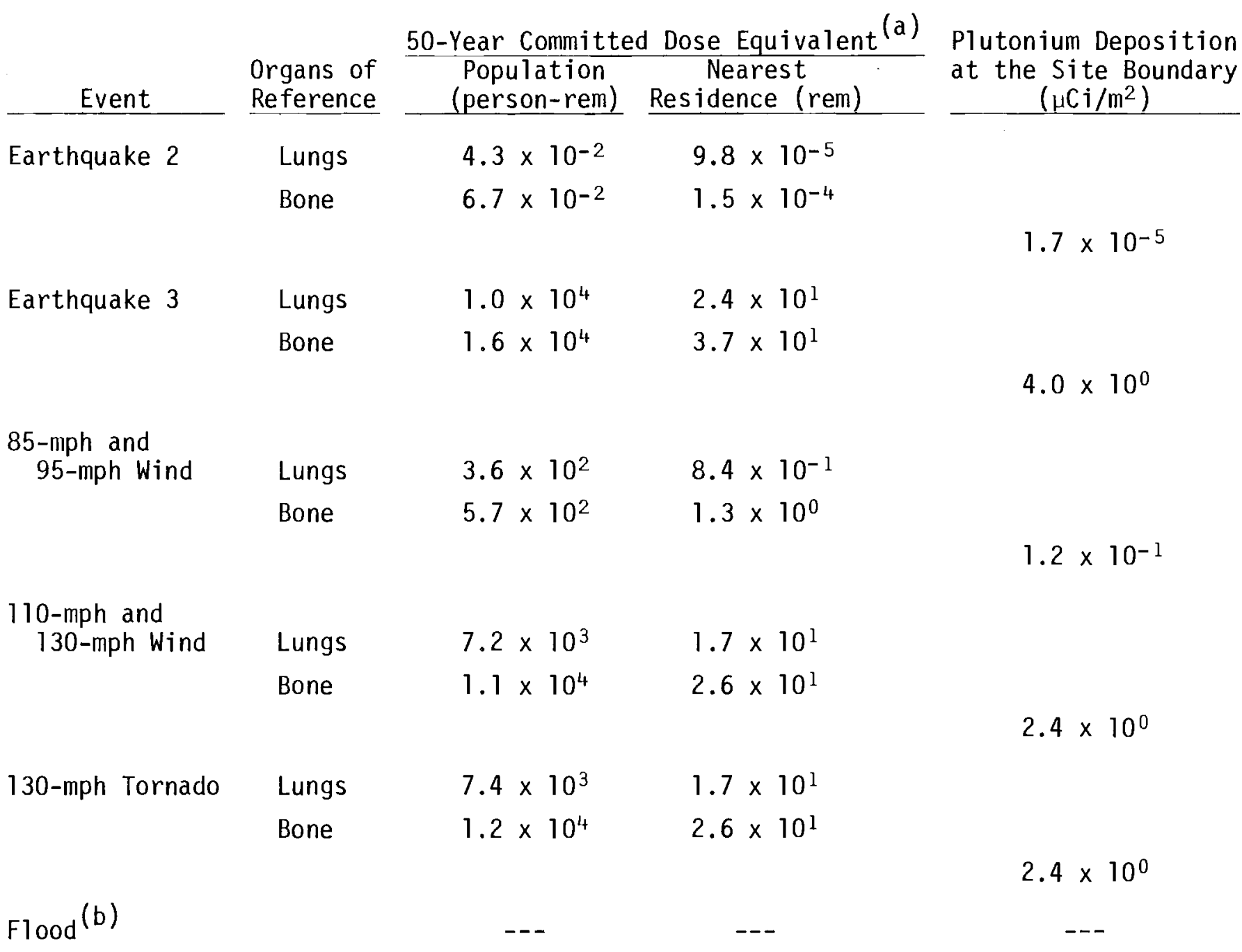

(a) A translocation Class $Y$ has been assumed.

(b) Outside probability range considered in this study. 


\section{CONTENTS}

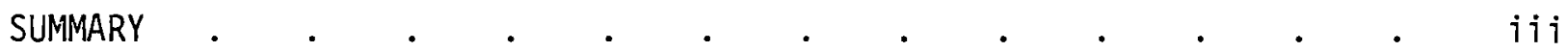

INTRODUCTION

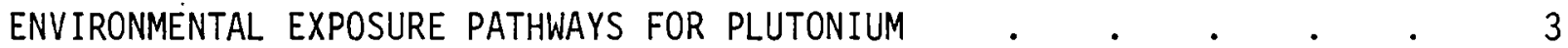

RADIATION DOSE MODELS FOR AN ATMOSPHERIC RELEASE . $\quad$. $\quad$. $\quad$. 5

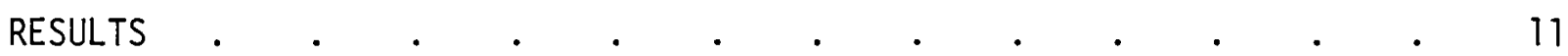

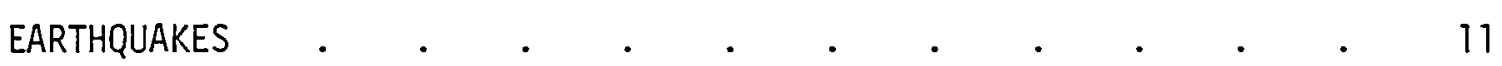

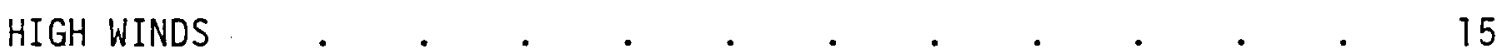

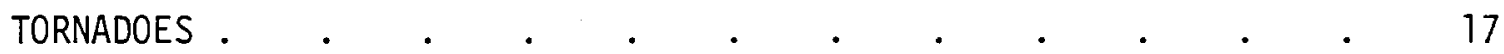

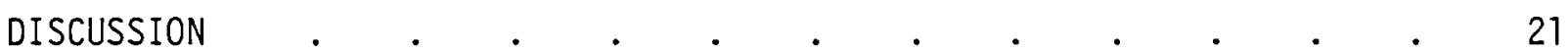

APPENDIX A - EVALUATION OF ENVIRONMENTAL PATHWAYS BY WHICH PLUTONIUM MAY REACH PEOPLE FROM AN ACCIDENTAL AIRBORNE RELEASE • . A A-1

APPENDIX B - DOSE FACTORS FOR INHALATION, AND DOSE CALCULATION RESULTS FOR CLASS W PLUTONIUM. . . . . . B- 1 


\section{$\underline{\text { TABLES }}$}

1 Most Likely 50-Year Committed Dose Equivalents and Maximum

Plutonium Deposition Values . . . . . . . . . . . . iv

2 Estimated Quantity of Plutonium Released to the Atmosphere

Following an Earthquake $. \quad . \quad . \quad . \quad . \quad . \quad . \quad . \quad . \quad 11$

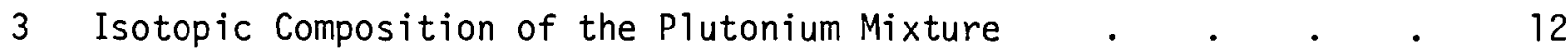

4 Fifty-Year Committed Dose Equivalents from Inhalation Following

Earthquake No. 2 . $\quad . \quad . \quad . \quad . \quad . \quad . \quad . \quad . \quad . \quad 13$

5 Fifty-Year Committed Dose Equivalents from Inhalation Following

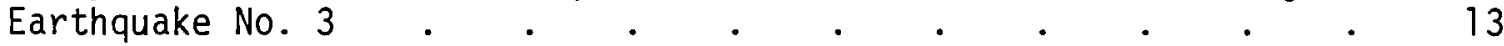

6 Estimated Maximum Plutonium Deposition at Significant Locations

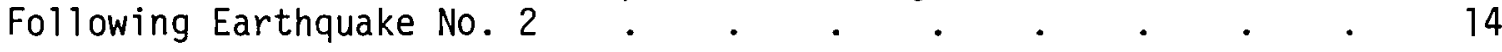

7 Estimated Maximum Plutonium Deposition at Significant Locations

Following Earthquake No. 3 . $.0 . \quad . \quad . \quad . \quad . \quad 14$

8 Estimated Quantity of Plutonium Released to the Atmosphere

Following a Severe High Wind . . . . . . . . . . 15

9 Fifty-Year Committed Dose Equivalents from Inhalation Following 85-mph and 95-mph Straight-Line Winds . . . . . . . . 16

10 Fifty-Year Committed Dose Equivalents from Inhalation Following 110-mph and 130-mph Straight-Line Winds . . . . . . 16

11 Estimated Maximum Plutonium Deposition at Significant Locations Following 85-mph and 95-mph Straight-Line Winds . . . . 17

12 Estimated Maximum Plutonium Deposition at Significant Locations Following 110-mph and 130-mph Straight-Line Winds ..$\quad$. 17

13 Estimated Quantity of Plutonium Released to the Atmosphere Following a 130-mph Tornado . . . . . . . . . . . 18

14 Fifty-Year Committed Dose Equivalents from Inhalation Following

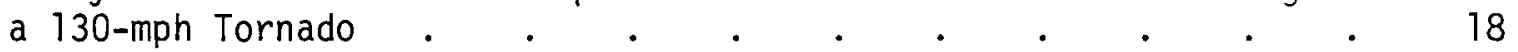

15 Estimated Maximum Plutonium Deposition at Significant Locations

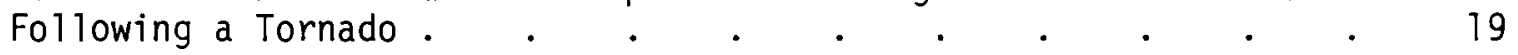

A.1 Fifty-Year Committed Dose Equivalents from Inhalation of $1 \mu \mathrm{m}$
AMAD $239 \mathrm{Pu}$ Particles
. 
A.2 Fifty-Year Committed Dose Equivalents from 50 Years' Inhalation of 1 um AMAD Resuspended 239 Pu Particles . . . . . . A-6

A.3 Air Submersion Doses from Exposure to ${ }^{239} \mathrm{Pu}$. . . . . . A-7

A.4 Fifty Years of External Exposure to $239 \mathrm{Pu}$ Deposited on the Ground A-8

A.5 Average ${ }^{239} \mathrm{pu}$ Concentration Estimated in Leafy Vegetables and Produce for a Five-Year Period . . . . . . . A-10

A.6 Fifty-Year Committed Dose Equivalents from 50 Years' Ingestion of Leafy Vegetables and Produce Contaminated with ${ }^{239} \mathrm{Pu}$. . . A-10

A.7 Average $239 \mathrm{Pu}$ Concentration Estimated in Grain and Forage for a Five-Year Period . . . . . . . . . A-12

A.8 Fifty-Year Committed Dose Equivalents from 50 Years' Ingestion of Milk and Beef Contaminated with ${ }^{239} \mathrm{Pu} .{ }^{2}$. . . . A-12

A.9 Fifty-Year Committed Dose Equivalents from 50 Years' Ingestion of Animal Products Contaminated with $239 \mathrm{Pu}$. . . . . A-15

A.10 Fifty-Year Committed Dose Equivalents from 50 Years' Consumption of Water Contaminated with ${ }^{239} \mathrm{Pu}$. . . . . . . . A-16

A.11 Fifty-Year Committed Dose Equivalents from 50 Years' Consumption of

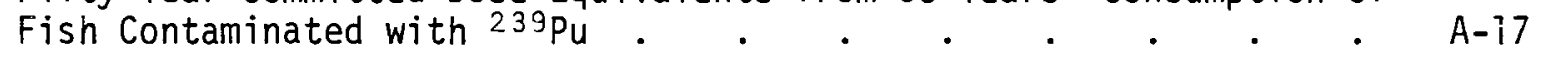

A.12 Fifty Years of External Exposure to ${ }^{239} \mathrm{Pu}$ from Swimming . . A-18

A.13 Fifty Years of External Exposure to $239 \mathrm{Pu}$ from Boating . . . A-18

A.14 Fifty Years of Shoreline Exposure to ${ }^{239} \mathrm{Pu}$. . . . . A-20

A.15 Fifty-Year Committed Dose Equivalents from an Acute Release of ${ }^{239} \mathrm{Pu}$ to the Atmosphere . . . . . . . . A-2?

B.1 Fifty-Year Committed Dose Equivalent Factors from Acute Inhalation. for Class W Material . . . . . . . . . .

B.2 Fifty-Year Committed Dose Equivalent Factors from Acute Inhalation for Class Y Material . . . . . . . . . B-1

B.3 Fifty-Year Committed Dose Equivalent Factors from One-Year Chronic Inhalation for Class W Material . . . . . .

B.4 Fifty-Year Committed Dose Equivalent Factors from One-Year Chronic Inhalation for Class Y Material . . . . . . . . . 
B.5 Fifty-Year Committed Dose Equivalents from Inhalation Following Earthquake No. 2 . $. \quad . \quad . \quad . \quad . \quad . \quad . \quad . \quad B-2$

B.6 Fifty-Year Committed Dose Equivalents from Inhalation Following Earthquake No. 3 . $. \quad . \quad . \quad . \quad . \quad . \quad . \quad . \quad B-3$

B.7 Fifty-Year Committed Dose Equivalents from Inhalation Following 85-mph and 95-mph Straight-Line Winds . . . . . . . B-3

B.8 Fifty-Year Committed Dose Equivalents from Inhalation Following 110-mph and 130-mph Straight-Line Winds . . . . . . B-4

B.9 Fifty-Year Committed Dose Equivalents from Inhalation Following a 130-mph Tornado . . . . . . . . . . . . B 


\section{INTRODUCTION}

This study estimates the potential environmental consequences in terms of radiation dose to people resulting from postulated plutonium releases accidentally caused by severe weather or other natural phenomena. The accident scenarios considered include earthquakes, tornadoes, high winds, and floods. This is one in a series of reports on commercial plutonium fabrication facilities sponsored by the U.S. Nuclear Regulatory Commission and coordinated by Argonne National Laboratory.

Figure 1 illustrates the information requirements for such a study and how the data are utilized to estimate dose. The amount and form of plutonium released into the atmosphere was estimated by Mishima et al. (1978). The atmospheric transport and dispersal of released plutonium was estimated by Pepper (1978) for tornadoes, ${ }^{(a)}$ by Carson for high winds, ${ }^{(b)}$ and by the NRC for earthquakes. (c) The site characteristics and demography around Leechburg, Pennsylvania were assembled by Frigerio. (b)

(a)Atmospheric dispersion values during a tornado at the Babcock and Wilcox Site were obtained from a letter transmitted from D. W. Pepper of SRL/ETD to R. B. McPherson of BNW/ESD, October 9, 1978.

(b) "Regional Demography, Topography and Land Use, Ecology, and Meteorology." Descriptions for the Babcock and Wilcox Facility transmitted by letter from J. E. Carson of ANL/EIS to J. E. Ayer of NRC/FCMS, November 8, 1977.

(c) "Meteorological Evaluations for Nuclear Facilities at Leechburg and Cheswick." Annual average atmospheric dispersion values for the B\&W Site transmitted by letters from L. G. Hulman of NRC/DSE to R. B. MCPherson of BNW/ESD, March 21 and May 25, 1978. 


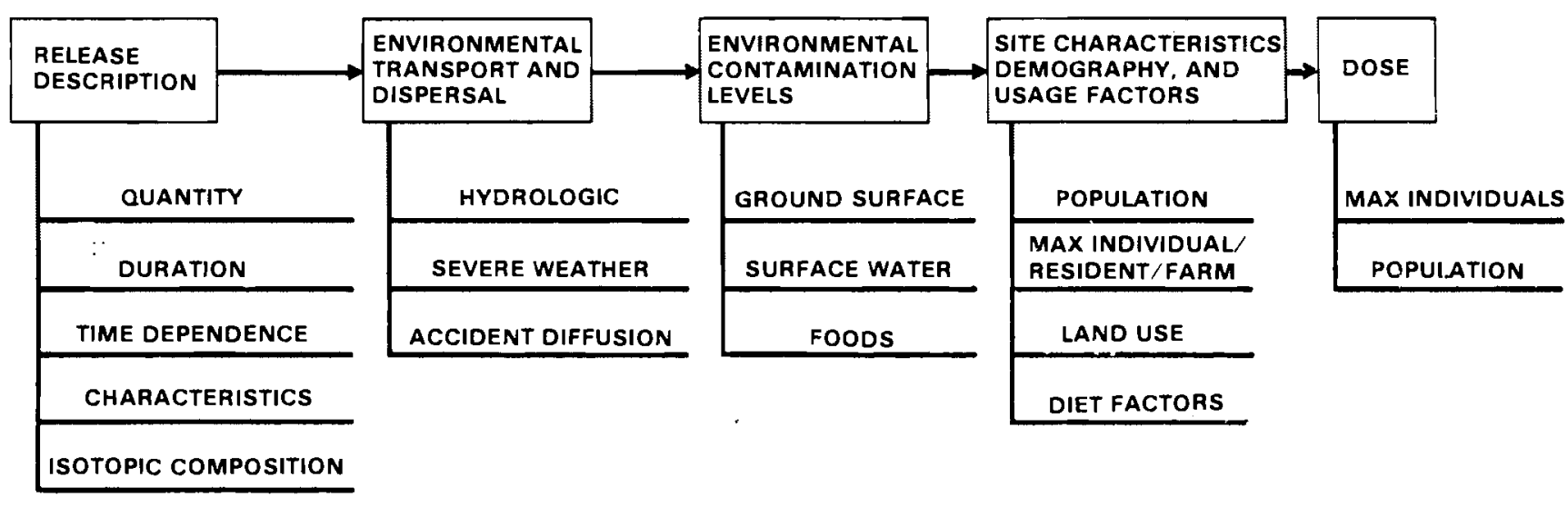

FIGURE 1. Accidental Environmental Consequences Evaluation 


\section{ENVIRONMENTAL EXPOSURE PATHWAYS FOR PLUTONIUM}

The potential environmental exposure pathways for radionuclides released to the atmosphere and water are shown in Figure 2. Our experience has shown that the more important pathways for exposure to atmospheric releases of plutonium and daughter products are inhalation, cloud submersion, ingestion, and direct ground irradiation. For chronic atmospheric releases of plutonium, the most important of these pathways is inhalation (Selby 1975, Friedman 1976, Anspaugh et a1. 1975, EPA 1977). It can also be shown that inhalation is the only important pathway for acute atmospheric releases of plutonium (see Appendix A). Therefore, only the radiation doses from inhalation during initial cloud passage and from inhalation of resuspended environmental residual contamination are calculated.

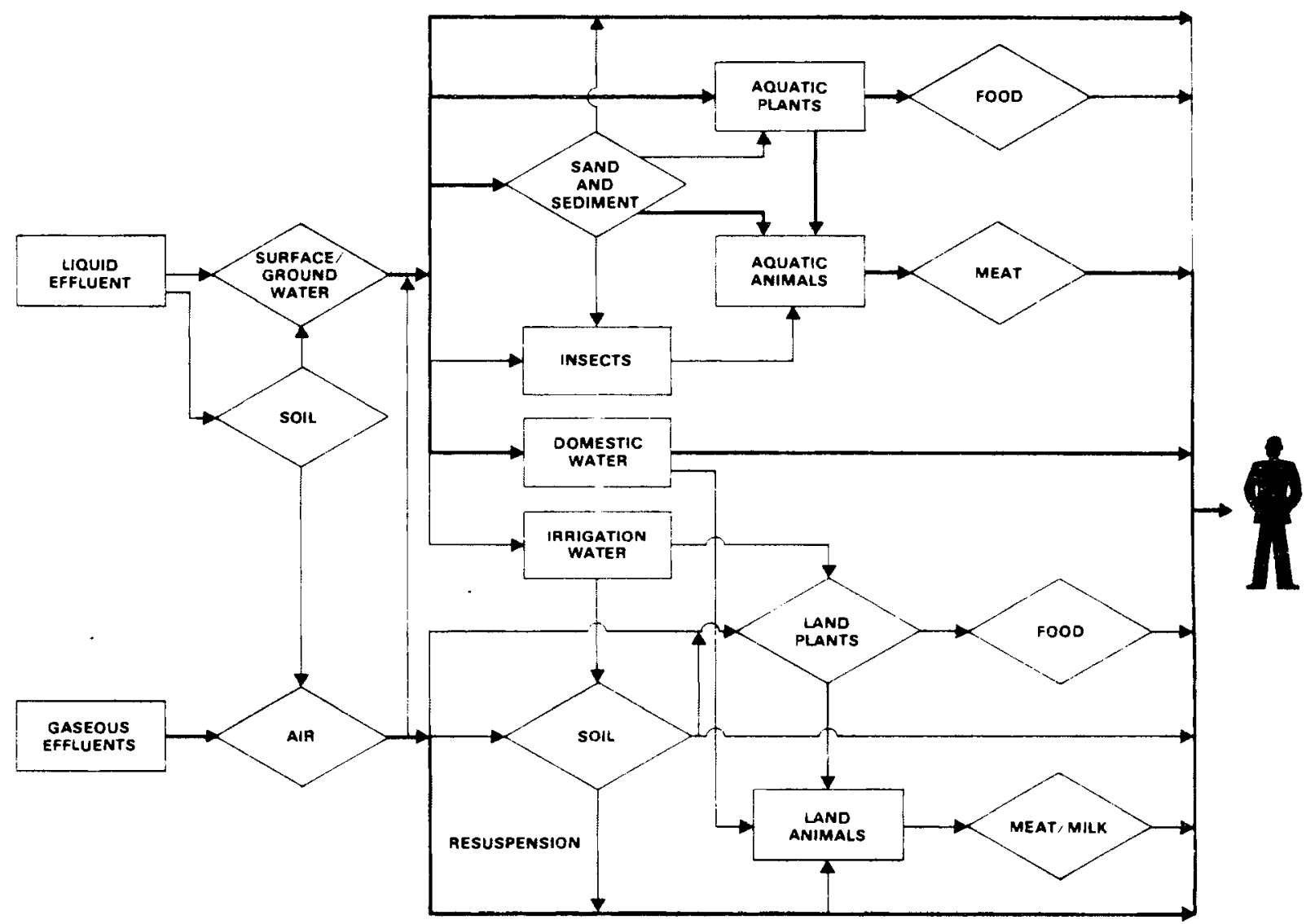

FIGURE 2. Potential Exposure Pathways for Radionuclides in the Biosphere 
For liquid releases during a flood, the important exposure pathways are aquatic food ingestion, water consumption, and shoreline exposure. Although irrigation with contaminated water and subsequent food ingestion may be an important exposure pathway, no irrigation is performed around the B\&W site. The significant potential exposure pathways that have been discussed are shown in Figure 3. The flood scenario was determined by the NRC to be outside the probability range considered in this study. (a) This scenario will not be considered further.

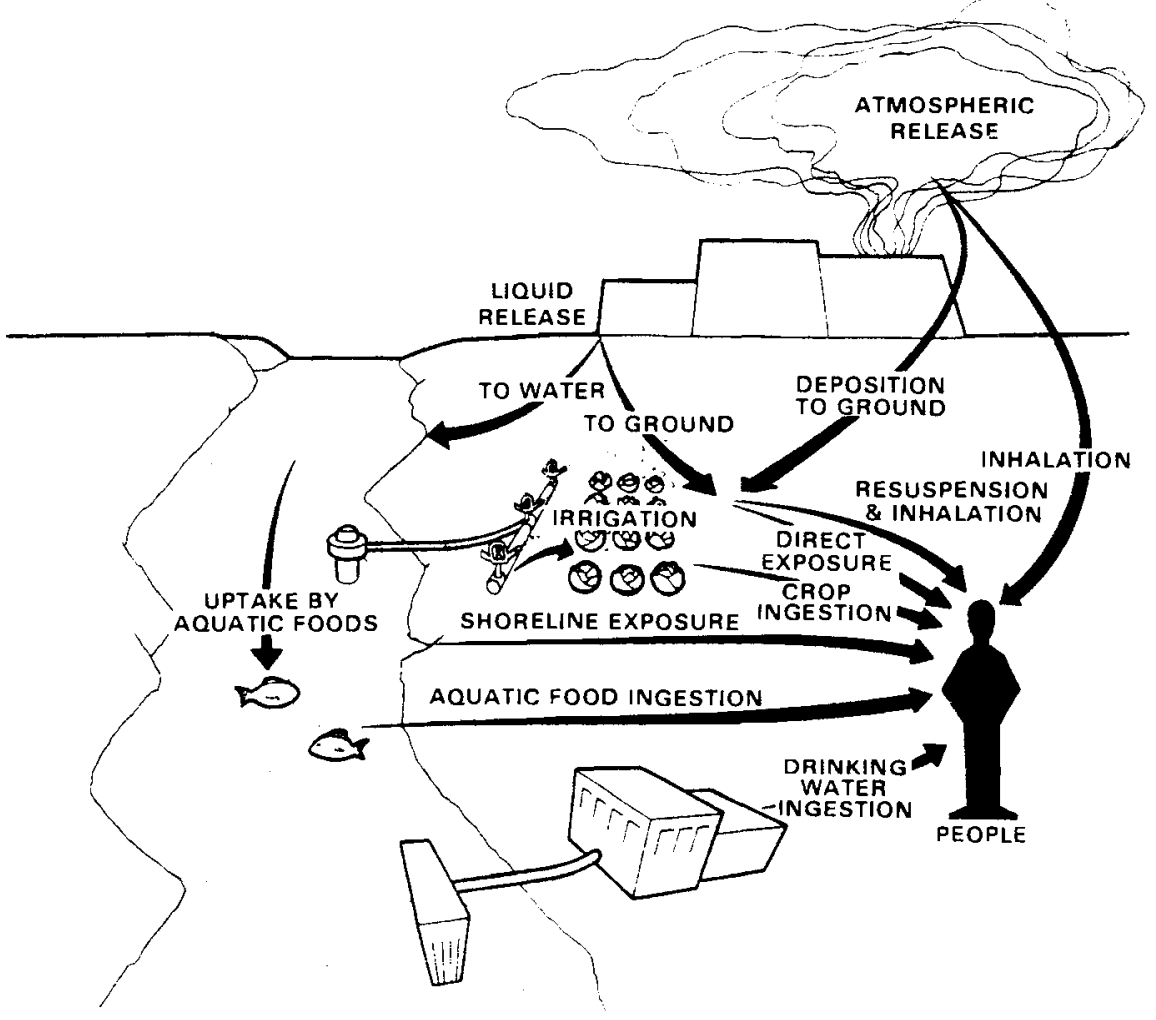

FIGURE 3. Significant Potential Exposure Pathways Through Which People May Be Exposed from an Accidental Release of Plutonium

(a)Derived from: "Assistance in Hydrologic Aspects - Analysis of the Effects of Natural Phenomena on Existing Plutonium Fabrication Facilities - Babcock and Wilcox." Transmitted by memorandum from L. G. Hulman of NRC/DSE to R. W. Starostecki of NRC/FCMS, July 3, 1978. 


\section{RADIATION DOSE MODELS FOR AN ATMOSPHERIC RELEASE}

The equation for calculating committed radiation dose equivalents from acute inhalation is:

$$
D C_{i r}=Q_{i}(E / Q)(B R)(D C F)_{i r}
$$

where

$D C_{i r}$ - the committed dose equivalent to organ $r$ from acute inhalation of radionuclide $i$, rem

$Q_{j}$ - the quantity of radionuclide $i$ released to the atmosphere, $\mu \mathrm{g}$

$E / Q$ - the accident atmospheric exposure coefficient, $\mu \mathrm{g} \cdot \mathrm{sec} / \mathrm{m}^{3} \mathrm{per}$ $\mu \mathrm{g}$ released

BR - the ventilation rate of the human receptor during the exposure period, $\mathrm{m}^{3} / \mathrm{sec}$

$(D C F)_{\text {ir }}$ - the acute committed dose equivalent factor, rem per $\mu$ inhaled; a number specific to a given nuclide $i$ and organ $r$ which can be used to calculate radiation dose from a given radionuclide intake.

Human ventilation rates for three time periods were derived from ICRP recommendations (ICRP 1975): $3.3 \times 10^{-4} \mathrm{~m}^{3} / \mathrm{sec}$ for the period $0-8$ hours; $2.3 \times 10^{-4} \mathrm{~m}^{3} / \mathrm{sec}$ for $8-24$ hours; and $2.7 \times 10^{-4} \mathrm{~m}^{3} / \mathrm{sec}$ for greater than 24 hours.

Fifty-year committed dose equivalent factors were calculated using the computer code DACRIN (Houston, Strenge and Watson 1975). This code incorporates the ICRP Task Group Lung Model (TGLM) to calculate the dose commitment to the lung and other organs of interest (ICRP 1966). The organ masses used in the code have been modified to reflect the changes reported in ICRP-23 (1975). The translocation of americium from the blood to the organs of interest has been changed to the values suggested in ICRP-19 (1972). 
Fifty-year committed dose equivalents per unit isotopic mass inhaled for particles with an AMAD ${ }^{(a)}$ of one micrometer are listed in Appendix $B$, Tables B.1 and B.2, for each plutonium isotope and ${ }^{241} \mathrm{Am}$. The organs of interest in plutonium dosimetry are the total body, kidneys, liver, bone, and lungs.

The plutonium postulated to be released to the atmosphere is in the form of plutonium oxides (Mishima et a1. 1978). Lung retention, as described by the TGLM, depends upon the chemical nature of the compound inhaled. Compounds of plutonium largely fall into Class $Y$ (retained for years) or Class $W$ (retained for weeks). There is no evidence of plutonium existing in the environment as Class $D$ (retained for days). Actinides in the oxide form are currently classified as Class Y (ICRP 1972), which is assumed in this study. Doses for plutonium as Class $W$ material, however, are included in Appendix $B$.

Plutonium particulates that deposit onto the ground surface from a plume can be resuspended to the atmosphere by natural processes, and subsequently inhaled by people. Therefore, ground contamination is an important factor when calculating doses via inhalation. Where deposition values were not provided (distances less than 5000 meters for the $0-2$ hour period following an earthquake), the deposition velocity concept was used to estimate the plutonium deposition (Equation 2).

$$
W_{i}=Q_{j}(E / Q) V_{d}
$$

where
$w_{i}$ - the concentration of radionuclide $i$ on the ground surface, $\mu \mathrm{g} / \mathrm{m}^{2}$
$Q_{i}$ - the quantity of radionuclide $i$ released to the atmosphere, $\mu \mathrm{g}$
E/Q - the accident atmospheric exposure coefficient, $\mu \mathrm{g} \cdot \mathrm{sec} / \mathrm{m}^{3} \mathrm{per}$ $\mu \mathrm{g}$ released
$V_{d}$ - particle deposition velocity, $\mathrm{m} / \mathrm{sec}$

(a)Activity median aerodynamic diameter 
The deposition velocity of plutonium particles cannot be specified exactly because it will vary depending on the size distribution of the particles, the nature of the surface on which deposition cccurs, the wind speed, and other meteorological variables. The deposition velocity for plutonium has been reported to range from $1 \times 10^{-4}$ to $3 \times 10^{-2} \mathrm{~m} / \mathrm{sec}$ (Selby et al. 1975, Cohen 1977, Baker 1977, Gudiksen et al. 1976, FES 1974). A value of $1 \times 10^{-3} \mathrm{~m} / \mathrm{sec}$ is used in this report (Baker 1977). Deposition values for tornadoes were reported by Pepper. (a) The NRC estimated deposition values during earthquakes and annual average conditions. (b) significant deposition downwind does not occur during high winds. (c)

Resuspension rates for material deposited on the ground are time dependent and tend to decrease with time after initial deposition. Local conditions can be expected to strongly affect the rate, with rainfall, winds, and surface characteristics predominant. The exact relationships are not wellenough understood to account for these effects (Selby et al. 1975). However, the airborne concentration from resuspended material can be estimated using a resuspension factor, $k$. The resuspension factor is defined as the resuspended air concentration divided by the surface deposition. Values for $k$ in the environment between $10^{-4}$ and $10^{-13} \mathrm{~m}^{-1}$ have been measured and reported (Selby et a1. 1975, Friedman 1976, Anspaugh et a1. 1975, EPA 1977, Cohen 1977, FES 1974, Bennett 1975, Hanson 1975, Martin and Bloom 1975, Sehmel 1977 , Healy 1977, Anspaugh 1976). Until a more general model is available, which considers 211 the important variables affecting the resuspension process, Anspaugh (1975) recommends using a simple time-dependent model to predict the average airborne concentration of a resuspended contaminant:

(a)Deposition values for the B\&W Site were obtained from a letter transmitted from D. W. Pepper of SRL/ETD to R. B. McPherson of BNW/ESD, October 9, 1978.

(b) "Meteorological Evaluations for Nuclear Facilities at Leechburg and Cheswick." Transmitted by memorandum from L. G. Hulman of NRC/DSE to R. B. McPherson of BNW/ESD, May 25, 1978.

(c) "Regional Demography, Topography and Land Use, Ecology, and Meteorology." Descriptions for the Babcock and Wilcox Facility transmitted by letter from J. E. Carson of ANL/EIS to J. E. Ayer of NRC/FCMS, November 8, 1977. 


$$
K(t)=10^{-4} \exp \left(-0.15 t^{\frac{1}{2}}\right)+10^{-9}
$$

where

$t$ - time since the material was deposited on the ground, days

$10^{-4}$ - resuspension factor at time $t=0, \mathrm{~m}^{-1}$

$10^{-9}$ - resuspension factor after 20 years, $\mathrm{m}^{-1}$

The second term in Equation $3,10^{-9} \mathrm{~m}^{-1}$, was added based on the assumption that there may be no further measurable decrease in the resuspension factor after 20 years. This assumption was deemed appropriate since the model was empirically derived to simulate experimental measurements out to 17 years, and contains no fundamental understanding of the resuspension process (Anspaugh et al. 1975). Figure 4 illustrates the time dependence of the resuspension factor.

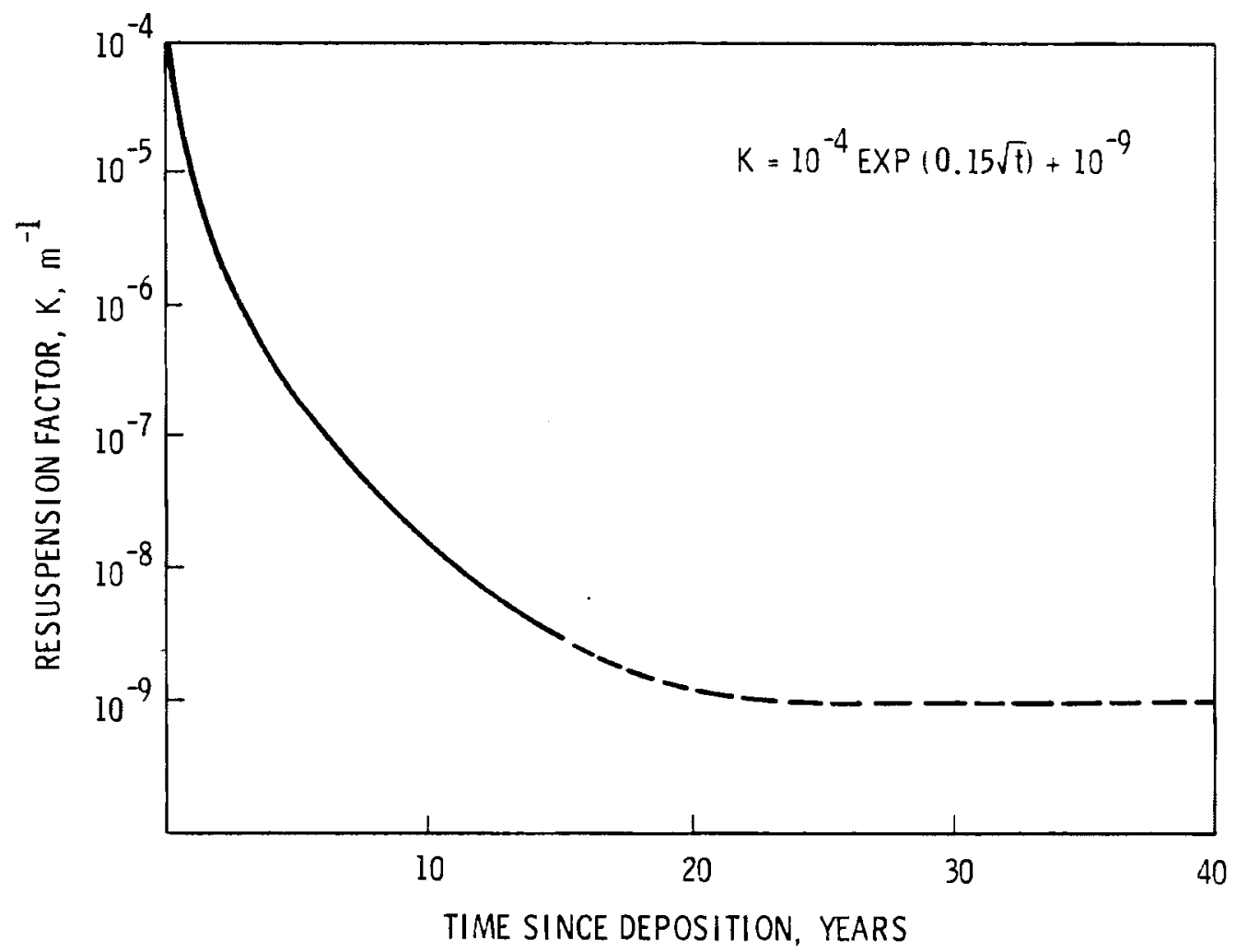

FIGURE 4. Time Dependence of the Environmental Surface Resuspension Factor 
Equation 3 was integrated over each year post-deposition and divided by the integrated time period to determine the average resuspension factor for each year considered. Ninety-nine percent of the total 50-year exposure from resuspension occurs in the first 5 years. The chronic 50-year committed dose equivalent factor for inhalation remains relatively constant over this time period. Therefore, the 50-year committed dose equivalent from 50 years of exposure to resuspended plutonium can be estimated using chronic 50-year committed dose equivalent factors, and only the first 5 years of exposure to the resuspended material needs to be included. The committed dose equivalent from inhalation of resuspended material was calculated by:

$$
D C_{i r}=W_{i} \bar{K}(B R)(D C F)_{\text {ir }}\left(3.16 \times 10^{7}\right)
$$

where

$D C_{i r}$ - the 50-year committed dose equivalent to organ $r$ from one year of inhalation of radionuclide $i$, rem/yr of inhalation

$w_{i}$ - the concentration of radionuclide $i$ on the ground surface for the year of consideration, $\mu \mathrm{g} / \mathrm{m}^{2}$

$\bar{K}$ - the average resuspension factor for the year of consideration, $m^{-1}$

$B R$ - the ventilation rate of the human receptor (for a duration of greater than 24 hours), $\mathrm{m}^{3} / \mathrm{sec}$

$(D C F)_{\text {ir }} \bullet$ chronic committed dose equivalent factor, rem/ug inhaled $3.16 \times 10^{7}$ - conversion factor, sec/yr

Radiological decay of the deposited radionuclides and the buildup of $241 \mathrm{Am}$ from the decay of $24 \mathrm{lPu}$ were accounted for. Chronic 50-year committed dose equivalent factors for a one-year intake were calculated using DACRIN and are listed in Appendix B, Tables B.3 and B.4. 


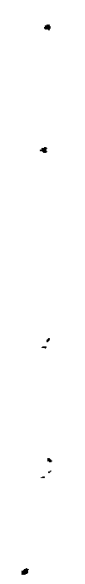




\section{RESULTS}

\section{EARTHQUAKES}

Committed radiation dose equivalents to several organs of the human body were calculated for two earthquake events using the source terms given in Table 2.

TABLE 2. Estimated Quantity of Plutonium Released to the Atmosphere Following an Earthquake(a)

\begin{tabular}{|c|c|c|c|c|}
\hline \multirow[b]{3}{*}{ Time Period } & \multicolumn{4}{|c|}{ Airborne Release of Plutonium $(\mathrm{g})$} \\
\hline & Earthql & No. 2 & Earthqu & No. 3 \\
\hline & Conservative & Most Likely & Conservative & Most Likely \\
\hline $0-2 \mathrm{hr}$ & $5 E-6^{(b)}$ & $1 E-6$ & $1 E+0$ & $2 E-1$ \\
\hline $2-8 \mathrm{hr}$ & $1 E-5$ & $3 E-6$ & $5 E+0$ & $4 E-1$ \\
\hline $8-24 h r$ & $2 E-5$ & $8 E-6$ & $1 E+1$ & $5 E-1$ \\
\hline 1-4 Days & $\underline{0}$ & $\underline{0}$ & $6 E+1$ & $\underline{2 E+0}$ \\
\hline Total & $4 E-5$ & $1 E-5$ & $8 E+1$ & $3 E+0$ \\
\hline
\end{tabular}

(a)Taken from Mishima et a1. (1978). Only the quantity released in the respirable particle size range (less than $10 \mu$ ) was used.

(b) $5 \mathrm{E}-6$ is identical to $5 \times 10^{-6}$.

Peak ground acceleration levels from 0.08 to $0.16 \mathrm{~g}$ were assumed for Earthquake No. 2, and from 0.20 to $0.29 \mathrm{~g}$ for Earthquake No. 3. Significant damage was not postulated for Earthquake No. 1, and the release for Earthquake No. 4 was estimated to be the same as No. 3 (Mishima et a1. 1978).

The isotopic composition assumed for the plutonium mixture used is based on the Environmental Impact Appraisal for B\&W prepared by the NRC (1978). The isotopic composition by weight percent is given in Table 3 .

For the 0-2 hour time period, accident atmospheric dispersion values for a 5\% and 50\% condition, calculated by the NRC for the Babcock and wilcox Site, were used to estimate potential committed dose equivalents to the population and a maximum individual. Annual average atmospheric dispersion and deposition values also calculated by the NRC were used for all other time periods. 
TABLE 3. Isotopic Composition of the Plutonium Mixture

$\begin{array}{lc}\text { Isotope } & \text { Weight Percent }(a) \\ 238 \mathrm{Pu} & 0.15 \\ 239 \mathrm{Pu} & 86 \\ 240 \mathrm{Pu} & 17 \\ 241 \mathrm{Pu} & 2.5 \\ 242 \mathrm{Pu} & 0.17 \\ 241 \mathrm{Am} & \frac{0.25}{100}\end{array}$

\footnotetext{
(a)A11 isotopic values including the sum have been rounded to two significant figures.
}

For the $5 \%$ condition (conservative), the annual average dispersion and deposition values were multiplied by a factor of 4 , as recommended by Carson. (a) Four combinations of release and dispersion are considered: most likely release with most likely dispersion; most likely release with conservative dispersion; conservative release with most likely dispersion; and conservative release with conservative dispersion. These combinations are referred to as Case I, Case II, Case III, and Case IV, respectively, and are used for all of the natural phenomena scenarios. The calculated committed dose equivalents via inhalation are listed in Tables 4 and 5 for the two earthquakes considered. The estimated maximum piutonium ground depositions at the site boundary, nearest residence, and farm are 1 isted in Tables 6 and 7 .

(a)Letter transmitted from J. E. Carson of ANL/EIS to R. B. McPherson of BNW/ESD, October 24, 1978. 
TABLE 4. Fifty-Year Committed Dose Equivalents from Inhalation Following Earthquake No. 2 (Class Y)

\begin{tabular}{|c|c|c|c|c|c|c|c|c|}
\hline \multirow{3}{*}{$\begin{array}{l}\text { Organ of } \\
\text { Reference }\end{array}$} & \multicolumn{8}{|c|}{ Committed Dose Equivalents for: } \\
\hline & \multicolumn{8}{|c|}{$\begin{array}{c}\text { Committed Dose Equivalents for: } \\
\text { Population (person-rem)(a) }\end{array}$} \\
\hline & Case I(c) & Case II & Case III & Case IV & Case I & Case II & Case & Case IV \\
\hline Total Body & $3.0 \mathrm{E}-3$ & $1.9 \mathrm{E}-2$ & $1.1 E-2$ & $8.0 \mathrm{E}-2$ & $6.9 E-6$ & $4.1 E-5$ & $2.5 E-5$ & $1.7 E-4$ \\
\hline Kidneys & 1. $3 \mathrm{E}-2$ & $8.5 E-2$ & $4.8 E-2$ & $3.5 \mathrm{E}-1$ & $3.1 E-5$ & $1.8 \mathrm{E}-4$ & 1. $1 \mathrm{E}-4$ & 7. $3 E-4$ \\
\hline Liver & $4.1 E-2$ & $2.6 E-1$ & $1.5 E-1$ & $1.1 E+0$ & $9.4 \mathrm{E}-5$ & $5.6 \mathrm{E}-4$ & $3.4 \mathrm{E}-4$ & $2.3 E-3$ \\
\hline Bone & $6.7 \mathrm{E}-2$ & $4.3 E-1$ & $2.4 \mathrm{E}-1$ & $1.8 \mathrm{E}+0$ & $1.5 E-4$ & $9.1 E-4$ & $5.5 E-4$ & $3.7 \mathrm{E}-3$ \\
\hline Lungs & $4.3 \mathrm{E}-2$ & $2.7 \mathrm{E}-1$ & $1.5 \mathrm{E}-1$ & $1.1 E+0$ & $9.8 E-5$ & $5.8 E-4$ & $3.5 E-4$ & $2.4 E-3$ \\
\hline
\end{tabular}

(a) Population within a $50-$ mile radius of the plant.

(b) Located 150 meters NE of the plant.

(c) Case I - most likely release with most likely dispersion; Case II - most likely release with conservative dispersion; Case III - conservative release with most likely dispersion; Case IV - conservative release with conservative dispersion.

TABLE 5. Fifty-Year Committed Dose Equivalents from Inhalation Following Earthquake No. 3 (Class Y)

Committed Dose Equivalents for:

\begin{tabular}{|c|c|c|c|c|c|c|c|c|}
\hline \multirow{2}{*}{$\begin{array}{l}\text { Organ of } \\
\text { Reference }\end{array}$} & \multicolumn{4}{|c|}{ Population (person-rem) } & \multicolumn{4}{|c|}{ Nearest Residence $(\mathrm{rem})(\mathrm{a})$} \\
\hline & Case & Case II & Case III & Case IV & Case I & Case II & Case III & Case IV \\
\hline Total Body & $7.3 E+2$ & $4.4 E+3$ & 1. $4 \mathrm{E}+4$ & $6.7 E+4$ & $1.7 E+0$ & $9.4 E+0$ & $3.3 E+1$ & $1.5 E+2$ \\
\hline Kidneys & $3.3 E+3$ & $1.9 \mathrm{E}+4$ & $6.4 E+4$ & $3.0 E+5$ & $7.4 E+0$ & $4.1 E+1$ & $1.5 E+2$ & $6.6 E+2$ \\
\hline Liver & $1.0 E+4$ & $5.9 E+4$ & $2.0 E+5$ & $9.1 E+5$ & $2.3 E+1$ & 1. $3 E+2$ & $4.5 E+2$ & $2.0 E+3$ \\
\hline Bone & $1.6 \mathrm{E}+4$ & $9.8 E+4$ & $3.2 E+5$ & $1.5 \mathrm{E}+6$ & $3.7 E+1$ & $2.1 E+2$ & $7.4 E+2$ & $3.3 E+3$ \\
\hline Lungs & $1.0 E+4$ & $6.2 E+4$ & $2.1 E+5$ & $9.5 E+5$ & $2.4 E+1$ & $1.3 E+2$ & $4.7 ㄷ+2$ & $2.1 E+3$ \\
\hline
\end{tabular}

(a) Located 150 meters NE of the plant. 
TABLE 6. Estimated Maximum Plutonium Deposition at Significant Locations Following Earthquake No. 2

\begin{tabular}{|c|c|c|c|c|}
\hline \multirow[b]{2}{*}{ Location } & \multicolumn{4}{|c|}{ Pu Deposition $\left(\mu \mathrm{Ci} / \mathrm{m}^{2}\right)$} \\
\hline & Case I & Case II & Case III & Case IV \\
\hline Site Boundary ${ }^{(a)}$ & $1.7 \mathrm{E}-5$ & $1.2 \mathrm{E}-4$ & $6.7 \mathrm{E}-5$ & $5.3 E-4$ \\
\hline Residence ${ }^{(b)}$ & $1.3 \mathrm{E}-5$ & $6.8 E-5$ & $4.2 E-5$ & $2.6 \mathrm{E}-4$ \\
\hline $\operatorname{Farm}^{(c)}$ & $1.2 \mathrm{E}-6$ & $6.8 E-6$ & $4.1 E-6$ & $2.6 \mathrm{E}-5$ \\
\hline
\end{tabular}

(a)Located 125 meters N of the plant.
(b)Located 150 meters NE of the plant.
(c)Located 600 meters NE of the plant.

TABLE 7. Es timated Maximum Plutonium Deposition at Significant Locations Following Earthquake No. 3

\begin{tabular}{|c|c|c|c|c|}
\hline \multirow[b]{2}{*}{ Location } & \multicolumn{4}{|c|}{ Pu Deposition $\left(\mu \mathrm{Ci} / \mathrm{m}^{2}\right)$} \\
\hline & Case I & Case II & Case III & Case IV \\
\hline Site Boundary (a) & $4.0 E+0$ & $2.6 \mathrm{E}+1$ & $6.9 E+1$ & $3.3 E+2$ \\
\hline Residence $(\mathrm{b})$ & $3.1 E+0$ & $1.6 \mathrm{E}+1$ & $6.6 \mathrm{E}+1$ & $2.8 E+2$ \\
\hline $\mathrm{Farm}^{(\mathrm{c})}$ & $3.0 \mathrm{E}-1$ & $1.6 \mathrm{E}+0$ & $6.6 \mathrm{E}+0$ & $2.8 \mathrm{E}+1$ \\
\hline
\end{tabular}

(a) Located 125 meters $N$ of the plant.

(b) Located 150 meters NE of the plant.

(c) Located 600 meters NE of the plant. 
HIGH WINDS

Four high, straight-line wind conditions were considered: $85 \mathrm{mph}$, $95 \mathrm{mph}, 110 \mathrm{mph}$ and $130 \mathrm{mph}$. The quantities of plutonium released to the atmosphere for these severe winds were estimated by Mishima (1978) and are reported in Table 8 .

TABLE 8. Estimated Quantity of Plutonium Released to the Atmosphere Following a Severe High Wind(a)

Airborne Release of Plutonium (g)

\begin{tabular}{|c|c|c|c|c|}
\hline \multirow[b]{2}{*}{ Time Period } & \multicolumn{2}{|c|}{ 85-mph and 95-mph winds } & \multicolumn{2}{|c|}{ 110-mph and 130-mph Winds } \\
\hline & Conservative & Most Likely & Conservative & Most Likely \\
\hline $0-2 \mathrm{hr}$ & $4 \mathrm{E}-2$ & $2 E-2$ & $1 E+0$ & $2 \mathrm{E}-1$ \\
\hline $2-8 h r$ & $8 \mathrm{E}-2$ & $1 E-2$ & $5 E+0$ & $4 E-1$ \\
\hline $8-24 h r$ & $2 E-1$ & $4 E-2$ & $1 E+1$ & $5 E-1$ \\
\hline 1-4 Days & $9 E-1$ & $1 E-1$ & $6 \mathrm{E}+1$ & $2 \mathrm{E}+0$ \\
\hline Total & $1 E+0$ & $2 E-1$ & $8 \mathrm{E}+1$ & $3 E+0$ \\
\hline
\end{tabular}

(a) Taken from Mishima et a1. (1978). Only the quantity released in the respirable particle size range was used.

For the 0- to 2-hour time period, the most likely atmospheric dispersion values were calculated by Carson. The wind was assumed to blow from the westerly directions (into the ENE, E, ESE, of SE sectors) (Fujita 1977). Annual average atmospheric dispersion and deposition values were used for all other time periods. The 0 - to 2-hour dispersion values and the annual average dispersion and deposition values were multiplied by a factor of 10 and 4 , respectively, to represent the conservative case. (a) significant deposition downwind does not occur during the 0 - to 2-hour period. Committed radiation dose equivalents calculated for several organs of the human body are given in Tables 9 and 10 for the four wind conditions. The estimated maximum plutonium deposits on the ground at the significant locations are listed in Tables 11 and 12 .

(a) Letter transmitted from J. E. Carson of ANL/EIS to R. B. McPherson of BNW/ESD, October 24, 1978. 
TABLE 9. Fifty-Year Committed Dose Equivalents from Inhalation Following 85-mph and 95-mph Straight-Line Winds (Class Y)

\begin{tabular}{|c|c|c|c|c|c|c|c|c|}
\hline \multirow{3}{*}{$\begin{array}{l}\text { Organ of } \\
\text { Reference }\end{array}$} & \multicolumn{8}{|c|}{ Committed Dose Equivalents for: } \\
\hline & \multicolumn{4}{|c|}{ Population (person-rem) } & \multicolumn{4}{|c|}{ Nearest Residence $(\mathrm{rem})(\mathrm{a})$} \\
\hline & Case I(B) & Case II & Case II I & Case IV & Case I & Case II & Case III & Case IV \\
\hline Total Body & $2.6 \mathrm{E}+1$ & $1.0 E+2$ & $2.0 E+2$ & $8.1 E+2$ & $5.9 \mathrm{E}-2$ & $2.3 \mathrm{E}-1$ & $4.7 \mathrm{E}-1$ & $1.9 \mathrm{E}+0$ \\
\hline Kidneys & $1.1 E+2$ & $4.5 E+2$ & $9.0 E+2$ & $3.6 E+3$ & $2.6 \mathrm{E}-1$ & 1. $.0 E+0$ & 2. $1 E+0$ & $8.2 E+0$ \\
\hline Liver & $3.5 E+2$ & $1.4 E+3$ & $2.8 E+3$ & 1. $1 E+4$ & $8.1 E-1$ & $3.2 E+0$ & $6.4 \mathrm{E}+0$ & $2.5 E+1$ \\
\hline Bone & $5.7 E+2$ & $2.3 E+3$ & $4.5 E+3$ & $1.8 \mathrm{E}+4$ & $1.3 \mathrm{E}+0$ & $5.2 \mathrm{E}+0$ & $1.0 \mathrm{E}+1$ & $4.1 E+1$ \\
\hline Lungs & $3.6 E+2$ & $1.5 \mathrm{E}+3$ & $2.9 E+3$ & $1.2 E+4$ & $8.4 \mathrm{E}-1$ & $3.3 \mathrm{E}+0$ & $6.7 \mathrm{E}+0$ & $2.6 \mathrm{E}+1$ \\
\hline
\end{tabular}

(a)Located 150 meters NE of the plant.

(b)Case I - most likely release with most likely dispersion; Case II - most likely release with conservative dispersion; Case II - conservative release with most likely dispersion; Case IV - conservative release with conservative dispersion.

TABLE 10. Fifty-Year Committed Dose Equivalents from Inhalation Following 110-mph and 130-mph Straight-Line Winds (Class Y)

Committed Dose Equivalents for:

\begin{tabular}{|c|c|c|c|c|c|c|c|c|}
\hline & & & & & \multirow{2}{*}{\multicolumn{4}{|c|}{ Nearest Residence $($ rem $)(a)$}} \\
\hline \multirow{2}{*}{$\begin{array}{l}\text { Organ of } \\
\text { Reference }\end{array}$} & \multicolumn{4}{|c|}{ (person-rem) } & & & & \\
\hline & Case & Case II & Case III & Case IV & Case I & Case II & Case I II & Case II \\
\hline Total Body & $5.1 E+2$ & $2.0 E+3$ & $1.3 \mathrm{E}+4$ & $5.2 E+4$ & $1.2 \mathrm{E}+0$ & $4.6 \mathrm{E}+0$ & $3.0 E+1$ & $1.2 E+2$ \\
\hline Kidneys & $2.2 E+3$ & $8.9 E+3$ & $5.7 E+4$ & $2.3 E+5$ & $5.1 E+0$ & $2.0 E+1$ & 1. $3 E+2$ & $5.2 E+2$ \\
\hline Liver & $6.9 E+3$ & $2.7 E+4$ & $1.8 \mathrm{E}+5$ & $7.0 E+5$ & $1.6 \mathrm{E}+1$ & $6.3 E+1$ & $4.1 E+2$ & $1.6 \mathrm{E}+3$ \\
\hline Bone & $1.1 E+4$ & $4.5 E+4$ & $2.9 E+5$ & $1.2 \mathrm{E}+6$ & $2.6 \mathrm{E}+1$ & $1.0 \mathrm{E}+2$ & $6.7 E+2$ & $2.6 E+3$ \\
\hline Lungs & $7.2 E+3$ & $2.9 E+4$ & $1.8 \mathrm{E}+5$ & $7.4 E+5$ & $1.7 E+1$ & $6.6 E+1$ & $4.3 E+2$ & $1.7 E+3$ \\
\hline
\end{tabular}

(a) Located 150 meters NE of the plant. 
TABLE 11. Estimated Maximum Plutonium Deposition at Significant Locations Following 85-mph and 95-mph Straight-Line Winds

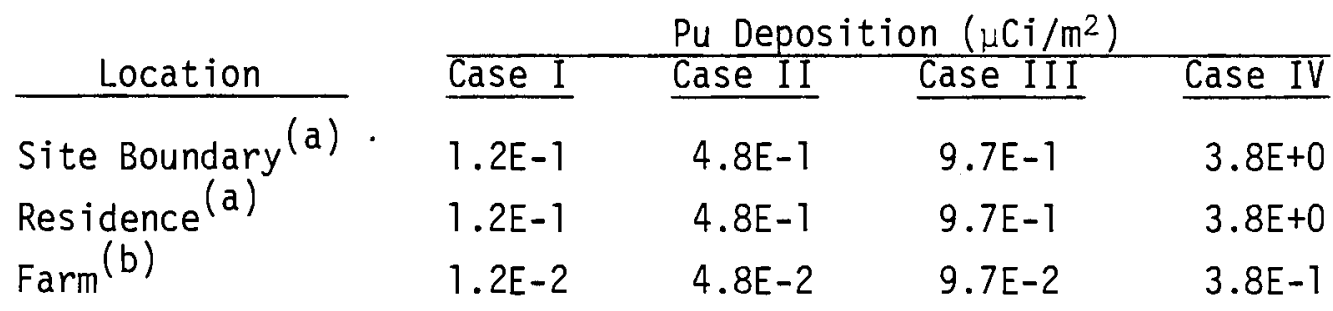

(a) Located 150 meters NE of the plant.

(b) Located 600 meters NE of the plant.

TABLE 12. Estimated Maximum Plutonium Deposition at Significant Locations Following 110-mph and 130-mph Straight-Line Winds

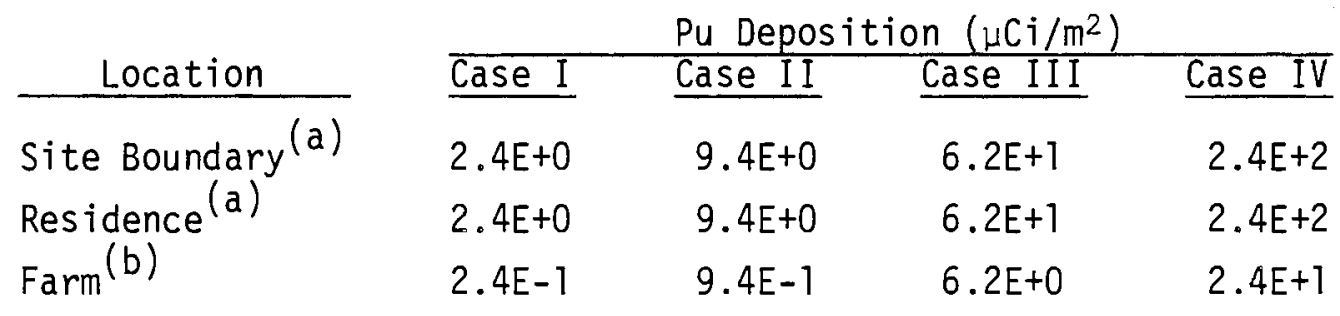

(a) Located 150 meters NE of the plant.

(b) Located 600 meters NE of the plant.

\section{TORNADOES}

Plutonium releases following a tornado with a maximum total wind speed of $110 \mathrm{mph}$ were estimated by Mishima (1978). Releases for four time periods are presented in Table 13.

Atmospheric dispersion and deposition values most likely to occur during a tornado were calculated by Pepper. These values were assumed to apply during the first two hours after the event. During this time period, the tornado was assumed to move in an $E$ to NE direction (Fujita 1977). Annual average atmospheric dispersion and deposition values were used for all other time periods. As recommended by Pepper ${ }^{(a)}$ and Carson, the tornado dispersion

(a) Letter transmitted from D. W. Pepper of SRL/ETD to R. B. McPherson of BNW/ESD, February 21, 1979. 
TABLE 13. Estimated Quantity of Plutonium Released to the Atmosphere Following a 130-mph Tornado(a)

\begin{tabular}{|c|c|c|}
\hline & \multicolumn{2}{|c|}{ Airborne Release of $\mathrm{Pu}(\mathrm{g})$} \\
\hline Time Period & Conservative & Most Likely \\
\hline $0-2 \mathrm{hr}$ & $1 E+0$ & $2 E-1$ \\
\hline $2-8 \mathrm{hr}$ & $5 \mathrm{E}+0$ & $4 E-1$ \\
\hline $8-24 h r$ & $1 E+1$ & $5 E-1$ \\
\hline 1-4 Days & $6 \mathrm{E}+1$ & $2 E+0$ \\
\hline Total & $8 E+1$ & $3 E+0$ \\
\hline
\end{tabular}

(a)Taken from Mishima et al. (1978). Only the quantity released in the respirable particle size range was used.

values were multiplied by a factor of 10 to represent the conservative case, and the annual average atmospheric dispersion and deposition values were again multiplied by a factor of 4 . Committed radiation dose equivalents are given in Table 14 for Class Y plutonium. The estimated maximum ground contamination levels from plutonium deposition at the significant locations are listed in Tabie 15.

TABLE 14. Fifty-Year Committed Dose Equivalents from Inhalation Following a 130-mph Tornado (Class Y)

\begin{tabular}{|c|c|c|c|c|c|c|c|c|}
\hline \multirow{3}{*}{$\begin{array}{l}\text { Organ of } \\
\text { Reference }\end{array}$} & \multicolumn{8}{|c|}{ Committed Dose Equivalents for: } \\
\hline & \multicolumn{4}{|c|}{ Population (person-rem) } & \multicolumn{4}{|c|}{ Nearest Residence $(\mathrm{rem})(\mathrm{a})$} \\
\hline & Case I(b) & Case II & Case III & Case IV & Case I & Case II & Case III & Case IV \\
\hline Total Body & $5.2 \mathrm{E}+2$ & $2.2 E+3$ & $1.3 E+4$ & $5.3 E+4$ & $1.2 E+0$ & $4.6 E+0$ & $3.0 E+1$ & $1.2 E+2$ \\
\hline Kidneys & $2.3 \mathrm{E}+3$ & $9.7 \mathrm{E}+3$ & $5.8 E+4$ & $2.3 E+5$ & $5.1 E+0$ & $2.0 E+1$ & 1. $3 E+2$ & $5.2 E+2$ \\
\hline Liver & $7.1 E+3$ & $3.0 E+4$ & $1.8 \mathrm{E}+5$ & $7.2 E+5$ & $1.6 \mathrm{E}+7$ & $6.3 E+1$ & $4.1 E+2$ & $1.6 \mathrm{E}+3$ \\
\hline Bone & $1.2 E+4$ & $4.9 E+4$ & 2. $9 E+5$ & $1.2 E+6$ & $2.6 \mathrm{E}+1$ & $1.0 E+2$ & $6.7 E+2$ & $2.6 E+3$ \\
\hline Lungs & $7.4 E+3$ & $3.1 E+4$ & $1.9 E+5$ & $7.5 E+5$ & $1.7 E+1$ & $6.6 \mathrm{E}+1$ & 4. $3 E+2$ & $1.7 E+3$ \\
\hline
\end{tabular}

(a) Located 150 meters NE of the plant.

(b) Case I - most likely release with most likely dispersion; Case II - most likely release with conservative dispersion; Case III - conservative release with most likely dispersion; Case IV - conservative release with conservative dispersion. 
TABLE 15. Estimated Maximum Plutonium Deposition at Significant Locations Following a Tornado

$\frac{\text { Location }}{\text { Site Boundary }}(\mathrm{a})$
Residence
Farm $^{(\mathrm{b})}$

\begin{tabular}{llcl}
\multicolumn{4}{c}{ Pu Deposition $\left(\mu \mathrm{Ci} / \mathrm{m}^{2}\right)$} \\
Case I & Case II & Case III & Case IV \\
$2.4 E+0$ & $9.4 E+0$ & $6.2 E+1$ & $2.4 E+2$ \\
$2.4 E+0$ & $9.4 E+0$ & $6.2 E+1$ & $2.4 E+2$ \\
$2.4 E-1$ & $9.4 E-1$ & $6.2 E+0$ & $2.4 E+1$
\end{tabular}

(a) Located 150 meters NE of the plant. (b) Located 600 meters NE of the plant. 



\section{$\underline{\text { DISCUSSION }}$}

For the tornado and severe wind events, the majority of the radionuclide intake occurs after the first two hours. At this time annual meteorology is assumed to resume.

The calculated committed dose equivalents are based on the ICRP Publication 2 Metabolic Model, the ICRP Task Group Lung Model and standard man parameter values. To the best of our knowledge, there are no reported assessments of the accuracy of dose calculations using these models and parameter values. Dose results are usually presented with no indication of the error associated with their use. Present insights into the degree of uncertainty involved are very limited and qualitative (Hoffman 1978). Dose results presented in this paper are probably within a factor of \pm 10 . However, studies should be conducted to determine the uncertainties associated with these kinds of calculations.

The dose rate from natural background radiation in the State of . Pennsylvania is reported to be $125 \mathrm{mrem} / \mathrm{yr}$ to the total body (Klement 1972). Therefore, an individual receives a total-body dose of about 6 rem from exposure to natural background radiation during a 50-year period. The collective dose equivalent from 50 years of exposure to natural background radiation to the total body of the population within a 50-mile radius of the Babcock and Wilcox Plant is $2 \times 10^{7}$ person-rem. The average annual dose to the total body of an individual from medical $x$-ray examination is about 20 mrem (United Nations 1977). This average dose corresponds to a 50-year collective dose equivalent of $3 \times 10^{6}$ person-rem. The dose contribution from fallout is negligible when compared to natural background radiation and medical $x$-ray exposure. If a radiation worker was involved in an occupational accident and received a maximum permissible bone burden of $239 \mathrm{Pu}$, the 50 -year committed dose equivalent to the bone would be greater than $1000 \mathrm{rem}$. As can be seen, then, the calculated 50-year committed dose equivalents to the population for the severe natural phenomena scenarios considered in this report are lower than the collective dose equivalent from 50 years of exposure to natural background radiation and medical $x$-rays. 
Existing guidelines on acceptable levels of soil contamination from $\mathrm{Pu}$ can be found to range from $0.01 \mu \mathrm{Ci} / \mathrm{m}^{2}$ to $270 \mu \mathrm{Ci} / \mathrm{m}^{2}$ (Selby et al. 1975; EPA 1977; Martin and Bloom 1975; Healy 1977; U.S. Code 1976; Healy 1974; Guthrie and Nichols 1964; Hazle and Crist 1975; Kathren 1968; Dunster 1962). The EPA has proposed a guideline of $0.2 \mu \mathrm{Ci} / \mathrm{m}^{2}$ for plutonium in the general environment (EPA 1977). This guideline is based on annual doses of one mrad to the lung from inhalation and three mrad to the bone from ingestion. If the broad range of current guidelines are normalized to these lung and bone doses and the same resuspension factor is used, the guidelines are all in reasonable agreement with $0.2 \mu \mathrm{Ci} / \mathrm{m}^{2}$.

The maximum residual plutonium contamination levels on the ground most likely to occur following the third and fourth earthquake, the 110-mph wind, and the two tornadoes are all above the EPA proposed guideline at the site boundary and nearest residence. The estimated contamination levels at these two locations range from about 2 to $4 \mu \mathrm{Ci} / \mathrm{m}^{2}$. At distances of 600 meters from the plant, where the closest farm is located, the contamination levels were estimated to be closer to the EPA proposed guideline. At the closest farm, the deposition values most likely to occur range from about 0.2 to $0.3 \mu \mathrm{Ci} / \mathrm{m}^{2}$. For the second earthquake event evaluated and the 85 and $95 \mathrm{mph}$ wind, the most likely ground contamination levels are well below the EPA proposed guideline at all significant locations. Ail conservative estimated residual contamination levels are above the EPA proposed guideline, except for the second earthquake event. 
APPENDIX A

EVALUATION OF ENVIRONMENTAL PATHWAYS BY WHICH PLUTONIUM MAY REACH PEOPLE FROM AN ACCIDENTAL AIRBORNE RELEASE 


\section{APPENDIX A}

\section{EVALUATION OF ENVIRONMENTAL PATHWAYS BY WHICH PLUTONIUM \\ MAY REACH PEOPLE FROM AN ACCIDENTAL AIRBONRE RELEASE}

Twelve environmental exposure modes for an accidental airborne release are considered for evaluation. Three are from exposure to the radioactive cloud, and four result from radioactive material deposited on the ground. The remaining five are via the waterborne pathway, assuming radioactive material was deposited onto a nearby surface body of water. For the Babcock \& Wilcox study, it is assumed that irrigation does not occur.

The following exposure modes are included in the study:

1. inhalation during the initial cloud passage,

2. inhalation of resuspended radioactive material,

3. direct exposure from cloud submersion,

4. direct exposure to radioactive material deposited on the ground,

5. ingestion of leafy vegetables, beef, milk, water and fish,

6. direct exposure from swimming and boating in contaminated water, and

7. external exposure to radioactive material concentrated in the shoreline sediment.

One isotope of plutonium is considered, ${ }^{239} \mathrm{pu}$, but the conclusions from this evaluation apply to most of the other isotopes, as well as a typical mixture of plutonium isotopes. The dose models used to evaluate the exposure modes are taken from Regulatory Guide 1.109, Revision 1 (1977) and are modified accordingly for an accidental release. In the evaluation, doses are calculated to a hypothetical maximum adult individual for 50 years of exposure. 


\section{AIRBORNE PATHWAYS}

Airborne Release Assumptions and Dispersion

A normalized plutonium release of $1 \mu \mathrm{g}{ }^{239} \mathrm{Pu}$ is assumed, and an arbitrary average accident exposure coefficient $(E / Q)$ of $1 \times 10^{-3} \mu \mathrm{g} \cdot \mathrm{sec} / \mathrm{m}^{3} \mathrm{per} \mu \mathrm{g}$ at the location of the maximum exposed individual is chosen. It is assumed that the particle size of the plutonium released is in the respirable range, less than $10 \mu \mathrm{m}$ in diameter.

Inhalation

The committed dose equivalent from radioactive material inhaled during passage of the initial cloud is calculated by:

$$
D C_{i}=Q(E / Q)(D C F)_{i}
$$

where

$$
\begin{aligned}
D C_{i} & \text { - committed dose equivalent to organ } i \text { (rem) } \\
Q & \text { - total quantity of radioactive material released during the } \\
& \text { accident }(\mu \mathrm{g}) \\
(E / Q) ~-~ & \text { accident atmospheric exposure coefficient }\left(\mu \mathrm{g} \cdot \mathrm{sec} / \mathrm{m}^{3} \mathrm{per} \mu \mathrm{g}\right) \\
(D C F)_{i} \text { - } & \text { committed dose equivalent factor for organ } i \\
& \left(\text { rem per } \mu \mathrm{g} \cdot \mathrm{sec} / \mathrm{m}^{3}\right)
\end{aligned}
$$

The committed dose equivalent factors for acute inhalation of ${ }^{239} \mathrm{Pu}$ were calculated using the computer code DACRIN (Houston et al. 1975). This code incorporates the ICRP Task Group Lung Model to calculate the dose to the lungs and other organs of interest. The organ masses were modified to reflect the changes reported in ICRP-23 (1975). The 50-year committed dose equivalent factors per unit mass exposure for ${ }^{239} \mathrm{Pu}$ particles, with an activity median aerodynamic diameter (AMAD) of one micrometer, are 1isted in Table A.1 for the total body, lungs, bone, and the lower large intestine (GI-LLI), along with the calculated committed dose equivalents. The translocation classes which minimize the contribution from the inhalation pathway are used. Cloud depletion is not considered. The location of the maximum exposed individual would 
TABLE A.1. Fifty-Year Committed Dose Equivalents from Inhalation of 1 um AMAD 239Pu Particles

\begin{tabular}{|c|c|c|c|}
\hline Organ & $\begin{array}{c}\text { Translocation } \\
\text { Class } \\
\end{array}$ & $\begin{array}{c}\text { Committed Dose } \\
\text { Equivalent Factors } \\
\left.\text { (rem per } \mu \mathrm{g} \cdot \mathrm{sec} / \mathrm{m}^{3}\right) \\
\end{array}$ & $\begin{array}{c}\text { Committed Dose } \\
\text { Equivalent } \\
\text { (rem) } \\
\end{array}$ \\
\hline Total Body & $Y$ & $5.6 E-04(b)$ & $5.6 E-07$ \\
\hline Lungs & $W$ & $9.9 E-04$ & $9.9 E-07$ \\
\hline Bone & Y & $1.2 E-02$ & $1.2 E-05$ \\
\hline GI-LLI & W & $7.3 E-07$ & $7.3 E-10$ \\
\hline
\end{tabular}

(a) At location where $E / Q=1 \times 10^{-3} \mu \mathrm{g} \cdot \mathrm{sec} / \mathrm{m}^{3} \mathrm{per} \mu \mathrm{g}$.

(b) $5.6 \mathrm{E}-04$ is identical to $5.6 \times 10^{-4}$.

probably be a few hundred meters from the point of release, and the inclusion of cloud depletion would only lower the doses by a few percent (USNRC Guide 1.111 1977, Gudiksen 1976).

Resuspension is an important aspect to be considered when calculating the dose from inhalation of plutonium. The airborne concentration from resuspended material can be predicted using a resuspension factor, $k$. The resus pension factor is defined as the resuspended air concentration divided by the surface deposition. Reasonable values for $\mathrm{k}$ between $10^{-4} \mathrm{~m}^{-1}$ and $10^{-13} \mathrm{~m}^{-1}$ have been measured and reported (Anspaugh 1975, Cohen 1977, Hanson 1975, FES 1974, Selby 1975, Bennett 1975, EPA 1977, Martin and Bloom 1975, Sehmel 1977, Healy 1977, and Anspaugh 1976). Until a more general model is available, which considers all the important variables affecting the resuspension process, Anspaugh (1975) recommends using a simple time-dependent model to predict the average airborne concentration of a resuspended contaminant:

$$
K(t)=10^{-4} \exp \left(-0.15 t^{\frac{1}{2}}\right)+10^{-9}
$$


where

$K$ - resuspension factor $\left(\mathrm{m}^{-1}\right)$

$t$ - time since the material was deposited on the ground (days)

The second term was added based upon the assumption that there may be no further measurable decrease in the resuspension process after 17 years, which is the longest period post deposition that measurements have been reported. This time-dependent model accounts for the observed decrease in air concentrations which has been noted to occur in the absence of a significant net loss of the deposited contaminant.

The resuspension factor was integrated over 50 years to include the total potential intake from resuspended plutonium. It was determined that $78 \%$ of the total 50-year exposure from resuspension occurs in the first year and $99 \%$ occurs in the first five years. To simplify the calculation, it is assumed that the total 50 years of exposure to resuspended plutonium is received during the first year, and the particle size is in the respirable range. The committed dose environment factor remains relatively constant over the first five years. Thus, bringing this term out of the integral does not affect the results. When Equation $\mathrm{A}-2$ is integrated over 50 years, the total exposure to resuspended material is calculated to be $8.9 \times 10^{-3}$ days/meter.

The committed dose equivalent from inhalation of resuspended material is calculated by:

$$
D C_{i}=w(D C F)_{j}\left(8.64 \times 10^{4}\right) \int_{0}^{T d} k(t) d t
$$

where

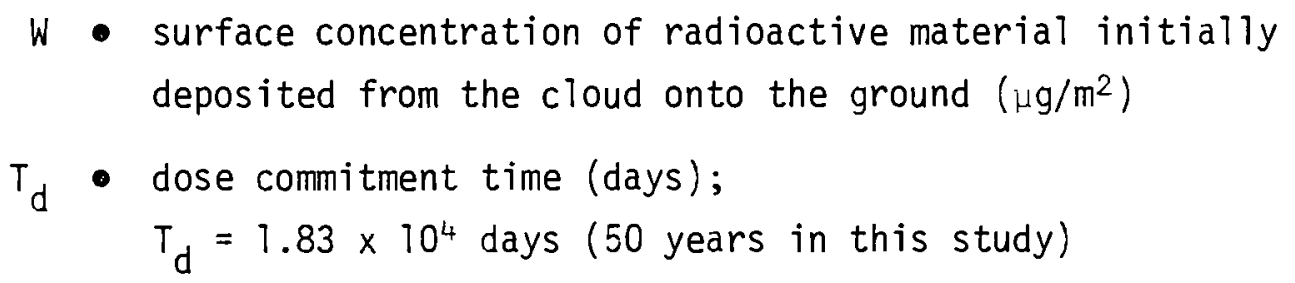


$(D C F)_{j} \quad$ - 50-year committed dose equivalent factor for organ $i$ (rem per $\mu \mathrm{g} \cdot \mathrm{sec} / \mathrm{m}^{3}$ )

$8.64 \times 10^{4}$ - constant which converts days to seconds (sec/day)

The terms $K$ and $D C_{i}$ have already been defined.

The initial ground deposition concentration for an accidental release of plutonium is calculated using the following equation:

$$
W=E V_{d}
$$

where

$E$ - exposure $\left(\mu \mathrm{g} \cdot \mathrm{sec} / \mathrm{m}^{3}\right)$, the product of $Q$ and $E / Q$ as defined earlier $V_{d}$ - deposition velocity $(\mathrm{m} / \mathrm{sec})$

A deposition velocity of $1 \times 10^{-3} \mathrm{~m} / \mathrm{sec}$ was chosen as is used in the computer code FOOD (Baker 1977).

Chronic committed dose equivalent factors were calculated for one year of inhalation of $239 \mathrm{Pu}$ using DACRIN (Houston et a1. 1975). The organ masses were modified to reflect the changes reported in ICRP-23 (1975) as before. The 50-year committed dose equivalent factors per unit mass inhaled during the first year for $239 \mathrm{Pu}$ particles with an AMAD of one micrometer are listed in Table A.2 for the total body, lungs, bone, and GI-LLI, along with the calculated committed dose equivalents. The translocation classes which minimize the contribution from inhalation are used to be consistent with Table A.l. 
TABLE A.2. Fifty-Year Committed Dose Equivalents from 50 Years' Inhalation of 1 um AMAD Resuspended 239 Pu Particles

\begin{tabular}{|c|c|c|c|}
\hline Organ & $\begin{array}{c}\text { Translocation } \\
\text { Class } \\
\end{array}$ & $\begin{array}{c}\text { Committed Dose } \\
\text { Equivalent Factors } \\
\left.\text { (rem per } \mu \mathrm{g} \cdot \mathrm{sec} / \mathrm{m}^{3}\right) \\
\end{array}$ & $\begin{array}{c}\text { Committed Dose } \\
\text { Equivalent a) } \\
\text { (rem) }\end{array}$ \\
\hline Total Body & Y & $4.6 E-04$ & $3.5 E-07$ \\
\hline Lungs & W & $8.1 E-04$ & $6.2 E-07$ \\
\hline Bone & $\gamma$ & $9.7 E-03$ & $7.5 E-06$ \\
\hline GI-LLI & $W$ & $5.9 E-07$ & $4.5 E-10$ \\
\hline
\end{tabular}

(a) At the same location where initial inhalation was calculated.

Cloud Submersion

A semi-infinite cloud model is used for calculating the external doses from cloud submersion during cloud passage. The doses are calculated with the following equation:

$$
D_{i}=E_{T}(D F)_{i} S_{F}
$$

where

$$
\begin{aligned}
& E_{T} \text { - sum of the initial exposure from initial cloud passage and } \\
& \text { resuspended radioactive material ( } \mu \mathrm{g} \cdot \mathrm{sec} / \mathrm{m}^{3} \text { ) } \\
& (D F)_{i} \text { - dose factor for cloud submersion for organ } i \\
& \text { (rem per } \mu \mathrm{g} \cdot \mathrm{sec} / \mathrm{m}^{3} \text { ) } \\
& S_{F} \text { - attenuation factor which accounts for shielding provided by } \\
& \text { residential structures (dimensionless) }
\end{aligned}
$$

The total exposure is calculated by:

$$
E_{T}=E+W\left(8.64 \times 10^{4}\right) \int_{0}^{T} K(t) d t
$$

where all terms have already been defined. 
The total exposure to the airborne particulate, $E_{T}$, is calculated to be $1.8 \times 10^{-3} \mu \mathrm{g}-\mathrm{sec} / \mathrm{m}^{3}$. A value of 0.70 is used for the attenuation factor, $S_{F}$ (USNRC Guide 1.109 1977).

Doses for submersion in a semi-infinite cloud of $239 \mathrm{Pu}$ were calculated using dose factors taken from Soldat (1974) and converted to dose per unit mass. The calculated doses and dose factors are given in Table A.3.

\section{TABLE A.3. Air Submersion Doses from Exposure to ${ }^{239} \mathrm{Pu}$}

\begin{tabular}{|c|c|c|c|}
\hline Organ & (rem & $\begin{array}{l}\text { Dose Factor } \\
\left.\text { per } \mu \mathrm{g} \cdot \mathrm{sec} / \mathrm{m}^{3}\right)\end{array}$ & Dose (rem) \\
\hline Total Body & & $9.6 E-13$ & $1.2 E-15$ \\
\hline Skin & & $1.3 E-11$ & $1.6 E-14$ \\
\hline
\end{tabular}

\section{Ground Exposure}

Dose from external exposure to radioactive material deposited on the ground is calculated by:

$$
D_{i}=W(D F)_{i} S_{F} T
$$

where

$(D F)_{i}$ - dose rate factor for organ $i$ (rem/hr per $\mu \mathrm{g} / \mathrm{m}^{2}$ )

$S_{F}$ - attenuation factor defined in Equation A-5 (dimensionless)

$T$ - time of exposure (hours)

W has been defined previously $\left(\mu \mathrm{g} / \mathrm{m}^{2}\right)$.

The assumption is made that the ground concentration of plutonium is constant (radiological decay is insignificant and was ignored), and the exposure time, $T$, is 50 years or $4.38 \times 10^{5}$ hours. A value of 0.70 is used for $S_{F}$ (USNRC Guide 1.109 1977).

The dose rate factors were again taken from Soldat et al. (1974) and converted to dose per unit mass. The calculated dose factors and doses are listed in Table A.4. 


\section{TABLE A.4. Fifty Years of External Exposure to $239 \mathrm{Pu}$ Deposited on the Ground}

$\begin{array}{lcc}\text { Organ } & \begin{array}{c}\text { Dose Rate Factor } \\ \left.\text { (rem/hour per } \mu \mathrm{g} / \mathrm{m}^{2}\right)\end{array} & \text { Dose (rem) } \\ \text { Total Body } & 4.9 \mathrm{E}-11 & 1.5 \mathrm{E}-11 \\ \text { Skin } & 4.8 \mathrm{E}-10 & 1.5 \mathrm{E}-10\end{array}$

\section{Crop Ingestion}

The internal committed dose equivalent received from ingestion of contaminated vegetation is calculated by Equation $A-8$.

$$
D C_{i}=C_{p} U_{p}(D C F)_{i}
$$

where

$$
\begin{aligned}
& \mathrm{U}_{\mathrm{p}} \text { - consumption rate for vegetation }(\mathrm{kg} / \mathrm{yr}) \\
& (D C F)_{i} \text { - 50-year committed dose equivalent factor for organ } i \text { from } \\
& \text { chronic ingestion of } 239 \mathrm{Pu} \text { (rem per } \mu \mathrm{g} \text { ingested per year) } \\
& C_{p} \text { - radionuclide concentration in the edible portion of the } \\
& \text { vegetation }(\mu \mathrm{g} / \mathrm{kg}) \text { : } \\
& C_{p}=\frac{W V_{d} r T_{r}\left(8.64 \times 10^{4}\right) \exp \left(-\lambda e^{t_{2}}\right)}{Y}\left[10^{-4} \int_{T_{1}}^{T_{2}} \exp \left(\lambda_{e} s-0.15 \sqrt{s}\right) d s\right. \\
& \left.+\frac{10^{-9}}{\lambda_{e}} \exp \left(\lambda_{e} t_{2}\right)-\exp \left(\lambda_{e} t_{1}\right)\right]+\frac{c_{0} r T_{r}}{\gamma} \exp \left[-\lambda_{e}\left(t_{2}-t_{1}\right)\right]
\end{aligned}
$$

where previously undefined symbols are defined by:

$r$ - fraction of deposited radionuclide retained by the vegetation (dimensionless)

$T_{r}$ - factor for translocation of externally deposited radionuclides to the edible parts of the vegetation (dimensionless) 


$$
\begin{aligned}
& Y \text { - vegetation yield }\left(\mathrm{kg} / \mathrm{m}^{2}\right) \\
& 8.64 \times 10^{4} \text { - constant which converts days to seconds ( } \mathrm{sec} / \text { days) } \\
& \lambda_{e} \text { - effective decay constant for removal of radionuclides on leaf } \\
& \text { or produce surfaces by weathering and radiological decay } \\
& \left(\text { days }^{-1}\right) \\
& t_{1} \text { - time from the accident to the appearance of the vegetation (days) } \\
& t_{2} \text { - time from the accident to harvest of the vegetation (days) } \\
& \mathrm{C}_{0} \text { - the concentration of radioactive material initially deposited } \\
& \text { on the vegetation }\left(\mu \mathrm{g} / \mathrm{m}^{2}\right) \text {; equals zero if the vegetation was } \\
& \text { not present at the time of the accident. }
\end{aligned}
$$

Equation A-9 accounts for the radioactive material initially deposited on the vegetation following the accident as we11 as the contribution from the deposit of resuspended environmental residual radioactive material.

The contribution from root uptake of plutonium is negligible compared to the plutonium deposited directly onto the vegetation (1ess than $1 \%$ ), and is ignored. It is assumed that the accident occurred a few days before harvest during the beginning of the growing season. A five-month growing season and a 90-day growing period for vegetation are used.

The integral was evaluated numerically. It was determined that almost a11 of the plutonium deposited on the vegetation occurs during the first year. Therefore, the assumption was made that the total intake occurs during the first year. Fifty-year committed dose equivalent factors were used to calculate the resulting committed dose equivalents.

Values for $r, Y$ and $\lambda_{e}$ are taken from Regulatory Guide 1.109 as 0.2 for particulates, $2.0 \mathrm{~kg} / \mathrm{m}^{2}$ for leafy vegetables and produce, and 0.0495 days $^{-1}$, respectively. Values of 1 , for leafy vegetables, and 0.1 , for produce, are used for $T_{r}$ (Baker et al. 1966). Consumption rates for the maximum individual are taken from Regulatory Guide 1.109 and adjusted for a five-month growing season. Consumption rates of $27 \mathrm{~kg} / \mathrm{yr}$, for leafy vegetables, and $217 \mathrm{~kg} / \mathrm{yr}$, for fruits, vegetables, and grain, were calculated. The average plutonium concentrations in the edible portion of leafy vegetables and produce are presented in Table A.5 for a five-year period. 
TABLE A.5. Average $239 \mathrm{Pu}$ Concentration Estimated in Leafy Vegetables and Produce for a Five-Year Period

\begin{tabular}{|c|c|c|}
\hline & \multicolumn{2}{|c|}{ Plutonium Concentration $(\mathrm{\mu g} / \mathrm{kg}$} \\
\hline Year (a) & Leafy Vegetables & Produce \\
\hline 1 & $4.7 E-08$ & $4.7 E-09$ \\
\hline 2 & $9.4 E-10$ & $9.4 \mathrm{E}-11$ \\
\hline 3 & $2.9 E-10$ & $2.9 E-11$ \\
\hline 4 & $1.2 E-10$ & $1.2 E-11$ \\
\hline 5 & $5.5 E-11$ & $5.5 E-12$ \\
\hline
\end{tabular}

(a) Accident occurred during first year, a few days before the first harvest.

Fifty-year committed dose equivalent factors for a one-year chronic ingestion of $239 \mathrm{Pu}$ were taken from NUREG-0172 (Hoenes and Soldat 1977), modified using updated organ masses from ICRP-23 (1975) and biological half-lives from ICRP-19 (1972), and converted to a unit mass intake. Committed dose equivalent factors and committed dose equivalents were calculated and are included in Table A.6.

TABLE A.6. Fifty-Year Committed Dose Equivalents from 50 Years' Ingestion of Leafy Vegetables and Produce Contaminated with $239 \mathrm{Pu}$

\begin{tabular}{lcr}
\multicolumn{1}{c}{ Organ } & $\begin{array}{c}\text { Committed Dose Equivalent } \\
\text { Factor (rem/50-year per } \\
\mu g \text { ingested per year) }\end{array}$ & $\begin{array}{c}\text { Committed Dose } \\
\text { Equivalent ( }\end{array}$ \\
\cline { 2 - 3 } Total Body & $1.2 E-03$ & $2.8 E-09$ \\
Bone & $4.5 E-02$ & $1.1 E-07$ \\
GI-LLI & $4.6 E-03$ & $1.1 E-08$
\end{tabular}

Ingestion of Milk and Beef

The internal committed dose equivalents from the ingestion of animal products (milk and beef) are calculated by:

$$
D C_{i}=\left[\sum(C Q)\right] \quad S U(D C F)_{i}
$$


where the summation of the product of the two terms, $C$ and $Q$, represents the tota 1 radionuclide intake by the animal from consumption of contaminated forage, feed, and water, and

$c$ - radionuclide concentration in the animal's food, $C_{f}$ ( $\mu g$ per $\mathrm{kg}$ forage or feed), or drinking water, $C_{w}$ ( $\mu \mathrm{g}$ per liter of water). Equation $A-9$ is used to determine values for $C_{f}$.

$Q$ - animals' consumption rate, $Q_{f}\left(\mathrm{~kg}\right.$ feed or forage/day), or $Q_{W}$ (e water/day)

S animal product transfer coefficient that relates the daily intake rate of an animal to the radionuclide concentration in milk, $S_{d}\left(\right.$ days $/ \ell$ ) and beef, $S_{b}$ (days $/ \mathrm{kg}$ )

$U$ - human consumption rate for milk, $U_{d}(\ell /$ year $)$, or beef, $U_{b}$ $(\mathrm{kg} /$ year $)$

$(D C F)_{j}$ - chronic ingestion committed dose equivalent factor for organ $i$ given in Table A.6 ( $r$ em/50-year per $\mu$ g ingested per year)

The dose contribution from the ingestion of milk or beef contaminated by the animal's drinking water is addressed in the next section.

An eight-month grazing season is assumed for both beef cattle and milk cows. For the remaining four months, the animals are fed stored feed and grain, which were grown during the previous five-month growing season. The radionuclide concentration in the grain is calculated using Equation A-9. The same parameters used to calculate the concentration in produce are used for grain. It is assumed that the accident occurred a few days before the harvest, during the beginning of the growing season. A 90-day growing period is used.

To estimate the average radionuclide concentration deposited on the pasture from the initial accident and resuspended radioactive material, Equation A-9 was integrated with respect to $t$, evaluated over the eight-month grazing season using a 30-day buildup period (USNRC Guide 1.109 1977), and divided by the integration time period of 30 days. A.1 other parameters remained unchanged, except that values of 1.0 (Baker et a1. 1966) and $0.70 \mathrm{~kg} / \mathrm{m}^{2}$ (USNRC Guide 1.109 1977) were used for $T_{r}$ and $Y$, respectively. 
It was determined that almost all of the plutonium deposited on the grain and pasture occurs during the first year. Regulatory Guide 1.109 uses a value of $50 \mathrm{~kg} /$ day for feed or forage consumption for both beef cattle and milk cows. Values for $S_{d}$ of $2.5 \times 10^{-8}$ days $/ \ell$ for milk and for $S_{b}$ of $5.0 \times 10^{-3}$ days $/ \mathrm{kg}$ for beef are reported by Baker (1966). Values for the human consumption rates are taken from Regulatory Guide 1.109 as $310 \mathrm{l}$ of milk/year and $110 \mathrm{~kg}$ beef/ year.

The average plutonium concentrations in the edible portion of the grain and in the fresh forage are presented in Table A.7 for a five-year period.

TABLE A.7. Average ${ }^{239} \mathrm{Pu}$ Concentration Estimated in Grain and Forage for a Five-Year Period

\begin{tabular}{|c|c|c|}
\hline \multirow{2}{*}{ Year $(a)$} & \multicolumn{2}{|c|}{ Plutonium Concentration $(\mathrm{\mu g} / \mathrm{kg})$} \\
\hline & Grain & Forage \\
\hline 1 & $4.7 \mathrm{E}-09$ & $2.7 \mathrm{E}-08$ \\
\hline 2 & $9.5 E-11$ & $1.4 \mathrm{E}-09$ \\
\hline 3 & $2.9 \mathrm{E}-11$ & $4.8 \mathrm{E}-10$ \\
\hline 4 & $1.2 \mathrm{E}-11$ & $2.0 E-10$ \\
\hline 5 & $5.5 \mathrm{E}-12$ & $9.9 \mathrm{E}-11$ \\
\hline
\end{tabular}

(a) Accident occurred at beginning of first year, 90 days into the growing and grazing season.

Using the 50-year ingestion committed dose equivalent factors given in Table A.6, committed dose equivalents were calculated for the consumption of contaminated animal products and are presented in Table A.8.

TABLE A.8. Fifty-Year Committed Dose Equivalents from 50 Years' Ingestion of Milk and Beef Contaminated with ${ }^{239} \mathrm{Pu}$

\begin{tabular}{|c|c|c|}
\hline Organ & $\frac{\text { Committed Dose }}{\text { Milk }}$ & $\begin{array}{c}\text { Equivalent (rem) } \\
\frac{\text { Beef }}{}\end{array}$ \\
\hline Total Body & $9.8 E-15$ & $6.9 E-10$ \\
\hline Bone & $3.7 E-13$ & $2.6 E-08$ \\
\hline GI-LLI & $3.7 E-14$ & 2.7E-09 \\
\hline
\end{tabular}




\section{WATERBORNE PATHWAYS}

To account for the contribution from radionuclides deposited onto a nearby surface body of water, a small lake one meter deep is assumed. Deposition over the lake is assumed to occur at the same rate as over land (USNRC Guide 1.111 1977). The plutonium is assumed to be soluble; however, it is most likely insoluble in water at normal pH levels. It is assumed that the radioactive particulates are uniformly mixed in the lake upon contact. $A$ four-year removal half-life is used (Wahlgren and Marshall 1975).

A differential equation was set up with a dynamic source term (this includes the initial deposition onto the water and the contribution from deposited resuspended material) to reflect the changing water concentration. When this equation is solved for the water concentration, an expression is obtained similar to Equation A-9. Due to the slower removal process (four years versus 14 days for vegetation), and since the majority of the radioactive material deposited on the lake takes place during the first year, the water concentration curve approaches a simple exponential expression. The initial water concentration can be determined by extrapolating the curve back to time zero, which yields Equation A-11.

$$
C_{W}=1.86 \times 10^{-9} \exp (-\lambda t)
$$

where

$C_{w}$ - radionuclide concentration in water $(\mu \mathrm{g} / \ell)$

$\lambda$ - removal constant for plutonium in the lake (days $^{-1}$ ); $\lambda=0.693 / 1461$ days $^{-1}$

$t$ - time since deposition onto the lake surface (days)

$1.86 \times 10^{-9}$ - extrapolated water concentration at $t=0(\mu \mathrm{g} / 2)$

Equation A-11 is much simpler than the complex solution obtained by solving the differential equation, and it only overestimates the water 
concentration by a few percent over the 50-year period considered. Equation 11 was integrated to estimate the average radionuclide concentration in the water for each year.

\section{Ingestion of Animal Products}

If the animals' drinking water supply was to come from the lake, a small fraction of the plutonium would eventually be transferred to the animals' milk or meat and be subsequentiy ingested by the maximum exposed individual. Since the potential radionuclide intake from this pathway occurs for approximately 30 years, ingestion committed dose equivalent factors must be calculated to account for the decreasing commitment time as the exposure time approaches the end of the 50-year exposure period. Committed dose equivalent factors for chronic ingestion of radionuclides are calculated with Equation $\mathrm{A}-12$.

$$
(D C F)_{i}=\left(2.92 \times 10^{-7}\right) S A\left(F_{w} \varepsilon / m\right)\left(\tau^{2}\right)\left[\lambda e^{t_{1}}+\exp \left(-\lambda e^{t_{2}}\right)-\exp (-\lambda \Delta t)\right]
$$

where

$(D C F)_{i}$ - committed dose equivalent factor for organ $i$ (rem per $\mu \mathrm{g}$ ingested per year)

$S A$ - specific activity of the radionuclide ( $\mathrm{pCi} / \mu \mathrm{g})$

$F_{w}$ - fraction of the ingested radionuclide reaching organ $i$ (dimensionless)

$\varepsilon$ - effective energy of the radionuclide in organ $i$ $[(\mathrm{MeV} / \mathrm{dis})(\mathrm{rem} / \mathrm{rad})]$

$m$ - mass of organ i $(g)$

$\tau$ - effective half-life of the radionuclide in organ $i$ (days)

$\lambda_{e}$ - effective decay constant in organ $i\left(\right.$ days $\left.^{-1}\right) ; \lambda_{e}=\ln 2 / \tau$

$t_{1}$ - duration of intake (days) 
$t_{2}$ - time over which the dose commitment is calculated, including the duration of intake (days)

$\Delta t \cdot\left(t_{2}-t_{1}\right) \geq 0$

One- through 50-year ingestion committed dose equivalent factors were calculated for $239 \mathrm{Pu}$ using parameter values found in ICRP-2 (1959), ICRP-23 (1975), and ICRP-19 (1972). The committed dose equivalent factor to the GI-LLI from ingestion does not change.

Committed dose equivalents were calculated using Equation A-10 for each year during the 50-year exposure period, using average yearly water concentrations and the appropriate dose commitment factor for that year. Baker (1966) and Regulatory Guide 1.109 use animal water consumption values of $60 \mathrm{l} /$ day for milk cows, and $50 \mathrm{l} /$ day for beef cattle. The total committed dose equivalents for the 50-year period to the maximum individual from ingestion of animal products for this exposure pathway are presented in Table A.9. The sum of the contributions from animal product ingestion for the airborne pathway and the waterborne pathway is also shown in Table A.9.

TABLE A.9. Fifty-Year Committed Dose Equivalents from 50 Years' Ingestion of Animal Products Contaminated with ${ }^{239} \mathrm{Pu}$ (waterborne pathway and waterborne plus air)

Total Committed Dose Committed Dose Equivalents Equivalents (rem) from Airborne (rem) from Waterborne Pathway and Waterborne Pathways

\begin{tabular}{|c|c|c|c|c|}
\hline Organ & in & Beef & \multicolumn{2}{|r|}{ rusimay } \\
\hline Total Body & $5.2 E-15$ & $3.1 E-10$ & 1. $5 E-14$ & $1.0 \mathrm{E}-09$ \\
\hline Bone & 2. $0 \mathrm{E}-13$ & $1.2 E-08$ & $5.7 E-13$ & $3.8 \mathrm{E}-08$ \\
\hline GI-LLI & 2. $3 \mathrm{E}-14$ & 1. $4 \mathrm{E}-09$ & $6.0 \mathrm{E}-14$ & 4.1E-09 \\
\hline
\end{tabular}

Drinking Water Ingestion

The committed dose equivalent from consumption of contaminated drinking water is calculated by:

$$
D C_{i}=\bar{C}_{w} U_{w}(D C F)_{j}
$$


where

$$
\begin{aligned}
& \begin{array}{l}
\bar{c}_{W} \text { - average radionuclide concentration in water during the year of } \\
\text { interest }(\mu g / l) \text {; calculated earlier }
\end{array} \\
& \begin{aligned}
U_{W} & \text { - consumption rate (l/year) }
\end{aligned} \\
& \begin{array}{l}
\text { A water consumption rate of } 730 \text { l/year is used (USNRC Guide } 1.109 \text { 1977). } \\
\text { (rem per } \mu g \text { ingested) }
\end{array} \\
& \text { Committed dose equivalent factors were calculated using Equation A-12. The } \\
& \text { dose calculations were taken out to } 28 \text { years, at which time the contribution } \\
& \text { to the total dose commitment from drinking water is insignificant. The } \\
& \text { resulting committed dose equivalents are listed in Table A.10. }
\end{aligned}
$$

\begin{tabular}{|c|c|}
\hline Organ & Committed Dose Equiv \\
\hline Total Body & $8.3 E-09$ \\
\hline Bone & $3.2 \mathrm{E}-07$ \\
\hline GI-LLI & $3.6 \mathrm{E}-08$ \\
\hline
\end{tabular}

TABLE A.10. Fifty-Year Conmitted Dose Equivalents from 50 Years' Consumption of Water Contaminated with ${ }^{239} \mathrm{Pu}$

\section{Fish Ingestion}

The equation used to estimate the dose from consumption of fish, assuming immediate transfer and equilibrium after deposition of the radionuclide onto the lake, is:

$$
D C_{i}=\bar{C}_{w} B U_{f}(D C F)_{i}
$$

where

$$
\begin{gathered}
\bar{c}_{w} \text { - average radionuclide concentration in the lake during the } \\
\text { year of interest }(\mu \mathrm{g} / \ell) \text {; calculated earlier }
\end{gathered}
$$


B - equilibrium bioaccumulation factor expressed as the ratio of the concentration in fish to the radionuclide concentration in water $(\ell / \mathrm{kg})$

$U_{f}$ - fish consumption rate ( $\mathrm{kg} /$ year)

$(D C F)_{i}$ - same committed dose equivalent factor calculated for the ingestion of animal products and drinking water, for organ $i$ (rem per $\mu \mathrm{g}$ ingested)

A fish consumption rate of $21 \mathrm{~kg} /$ year is used (USNRC Guide 1.109 1977) and the value for the bioaccumulation factor, $B$, is selected to be $3.5 \mathrm{l} / \mathrm{kg}$ (Soldat et al. 1974). The duration of fish consumption is assumed to be 50 years. However, the contribution from the last 22 years of fish consumption is negligible.

The committed dose equivalents from fish consumption were calculated and are given in Table A.11.

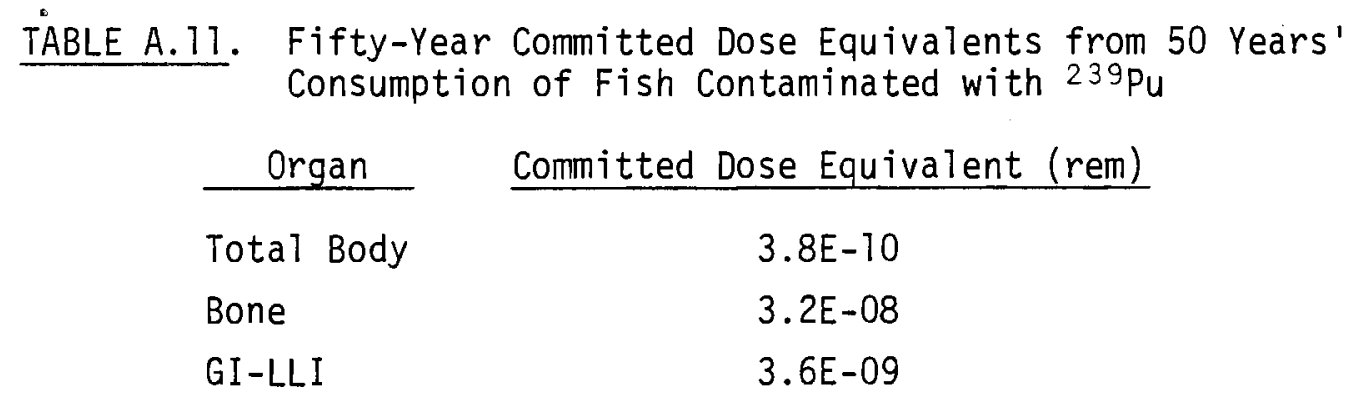

Swimming and Boating

The following equation is used to calculate the dose from swimming:

$$
D_{i}=\bar{C}_{w}(D F)_{i} \cup T
$$

where

$\bar{c}_{w}$ - average radionuclide concentration in the lake during the period of exposure $(\mu \mathrm{g} / \mathrm{l})$; calculated earlier 
$(D F)_{i}$ - water immersion dose rate factor for organ $i(r e m / h r$ per $\mu \mathrm{g} / \ell)$

$U$ - exposure rate (hours/year)

- period of exposure (years)

The dose rate factors were taken from Soldat et a1. (1975) and converted to dose per unit mass. Equation A-11 was integrated over a 50-year period and divided by 50 years to obtain an average radionuclide concentration in the lake during the period of exposure of $2.1 \times 10^{-10} \mathrm{\mu g} / \mathrm{l}$. Using a value of $100 \mathrm{hrs} /$ year for the exposure rate (Soldat et a1. 1974), and assuming a 50-year exposure time, the doses from swimming were calculated and are listed, along with the dose rate factors, in Table A. 12 .

TABLE A.12. Fifty Years of External Exposure to $239 \mathrm{Pu}$ from Swimming

\begin{tabular}{|c|c|c|}
\hline Organ & $\begin{array}{c}\text { Dose Rate Factor } \\
\text { (rem/hour per } \mu \mathrm{g} / 1 \text { iter) } \\
\end{array}$ & Dose (rem) \\
\hline Total Body & $7.4 E-09$ & $7.8 E-15$ \\
\hline Skin & $1.1 E-07$ & $1.2 E-13$ \\
\hline
\end{tabular}

The doses received from boating are calculated using Equation 15 and by dividing the dose rate factors by 2 , to correct for the geometry (Soldat et a1. 1974). The same values assumed for $U$ and $T$, in the dose calculations for swimming, are used (Soldat et a1. 1974). The doses for boating are given in Table A.13.

TABLE A.13. Fifty Years of External Exposure to $239 \mathrm{Pu}$ from Boating

$\begin{array}{lr}\frac{\text { Organ }}{\text { Total Body }} & \begin{array}{l}\text { Dose }(\text { rem }) \\ \text { Skin }\end{array} \\ \begin{array}{ll}3.9 \mathrm{E}-15 \\ 5.8 \mathrm{E}-14\end{array}\end{array}$




\section{Shore Tine Exposure}

The doses received from exposure to shoreline deposits are calculated by:

$$
D_{i}=U(D F)_{i} \bar{C}_{S} T
$$

where

$$
\begin{aligned}
U & \text { - exposure rate (hours/year) } \\
(D F)_{i} & \text { - dose factor for organ } \left.i \text { given in Table } 4 \text { (rem/hour per } \mu \mathrm{g} / \mathrm{m}^{2}\right) \\
\bar{C}_{\mathrm{S}} & \text { - average radionuclide surface concentration in the top } 2.5 \mathrm{~cm} \\
& \text { of shoreline sediments }\left(\mu \mathrm{g} / \mathrm{m}^{2}\right) \\
T & \text { - period of exposure (years) }
\end{aligned}
$$

A differential equation was set up to represent the buildup of radionuclide concentration in the shoreline sediments from the transport of the radionuclide particulates in the water adjacent to the sediment. The procedure is similar to that discussed in Regulatory Guide 1.109, Rev. 1, except that the water concentration is decreasing with time. Assuming a sediment surface density of $40 \mathrm{~kg} / \mathrm{m}^{2}$ (USNRC Guide 1.109 1977) and a water-to-sediment transfer coefficient of $7.2 \times 10^{-2} \mathrm{l} / \mathrm{kg}$ per hour (USNRC Guide 1.109 1977), ignoring radiological decay, and using Equation A-11 to predict the water concentration, the following equation for the sediment surface concentration is obtained:

$$
C_{S}=C_{S}^{0}+\left(1.29 \times 10^{-7}\right) S_{W}[1-\exp (-\lambda t)] / \lambda
$$

where

$C_{s}^{0}$ - the surface concentration of radioactive material initially deposited from the cloud onto the sediments $\left(\mu \mathrm{g} / \mathrm{m}^{2}\right)$; same as $W$ defined in Equation $A-4$ 
$1.29 \times 10^{-7}$ - the extrapolated water concentration at $t=0,1.86 \times 10^{-9} \mu \mathrm{g} / \mathrm{l}$, times the water-to-sediment transfer coefficient, $7.2 \times 10^{-2} \mathrm{l} / \mathrm{kg} \cdot \mathrm{hr}$, times the sediment surface density, $40 \mathrm{~kg} / \mathrm{m}^{2}$, times $24 \mathrm{hr} /$ day $\left(\mu \mathrm{g} / \mathrm{m}^{2}\right.$ per day)

$S_{w}$ - shore-width factor that describes the geometry of the exposure (dimensionless)

$\lambda$ - removal constant for plutonium in a lake, defined in Equation A-11 (days ${ }^{-1}$ )

$t$ - time since deposition onto the lake surface (days)

A shore-width factor of 0.3 is assumed for a lake shore (USNRC Guide 1.109 1977). Equation A-17 was integrated over a 50-year period and divided by 50 years to obtain an average radionuclide surface concentration in the sediments of $7.3 \times 10^{-5} \mathrm{\mu g} / \mathrm{m}^{2}$, during the period of exposure. Using an exposure rate of $50 \mathrm{hrs} /$ year (Soldat et al. 1974), doses were calculated for a 50-year period and are listed in Table A.14.

TABLE A.14. Fifty Years of Shorel ine Exposure to ${ }^{239} \mathrm{Pu}$

\begin{tabular}{|c|c|}
\hline Organ & Dose (rem) \\
\hline Total Body & $8.9 E-11$ \\
\hline Skin & $8.8 \mathrm{E}-10$ \\
\hline
\end{tabular}


SUMMARY OF FIFTY-YEAR COMMITTED DOSE EQUIVALENTS

FROM ALL MODES OF EXPOSURE

A summary of the 50-year committed dose equivalents from all modes of exposure is given in Table A.15. The inhalation exposure mode contributes greater than $98 \%$ of the total dose to the total body, lungs, and bone. A11 other exposure modes contribute less than 1\%, except water consumption, which contributes $1.6 \%$ to the total bone dose. The assumptions used for this exposure mode were very conservative, and, in reality, this mode of exposure is not expected to contribute significantly. Therefore, for accidental airborne releases of plutonium, only inhalation from initial cloud passage and resuspension requires consideration. Resuspension could contribute as much as $39 \%$ of the total dose to the total body, lungs, and bone from inhalation, if a11 plutonium particles released and available for resuspension are in the respirable range.

The dose equivalents to the skin and GI-LLI are insignificant when compared to the lungs and bone dose, and can be ignored. Although $239 \mathrm{Pu}$ was the only isotope considered, these conclusions apply to most isotopes of plutonium and a typical mixture of plutonium isotopes. 
IABLE A.15. Fifty-Year Committed Dose Equivalents from an Acute Release of ${ }^{239} \mathrm{Pu}$ to the Atmosphere

\begin{tabular}{|c|c|c|c|c|c|}
\hline & Fifty-Year & Committed Dose & Equivalents (rem & to the Followi & a Organs. \\
\hline Exposure Mode & Total Body & Skin & Lungs & Bone & GI-LLI \\
\hline Initial Inhalation & $5.6 \mathrm{E}-07 \quad(61)$ & & $9.9 \mathrm{E}-07 \quad(61)$ & $1.2 E-05(60)$ & $7.3 \mathrm{E}-10(1.3)$ \\
\hline $\begin{array}{l}\text { Inhalation from } \\
\text { Resuspension }\end{array}$ & $3.5 \mathrm{E}-07 \quad(38)$ & & $6.2 \mathrm{E}-07 \quad(39)$ & $7.5 E-06(38)$ & $4.5 E-10(0.8)$ \\
\hline Cloud Submersion & $1.2 \mathrm{E}-15 \quad(<0.1)$ & $1.6 \mathrm{E}-14 \quad(<0.1)$ & $1.2 \mathrm{E}-15(<0.1)$ & $1.2 \mathrm{E}-15 \quad(<0.1)$ & $1.2 E-15 \quad(<0.1)$ \\
\hline Ground Exposure & $1.5 \mathrm{E}-11 \quad(<0.1)$ & $1.5 E-10(15)$ & $1.5 E-11 \quad(<0.1)$ & $1.5 \mathrm{E}-11 \quad(<0.1)$ & $1.5 E-11 \quad(<0.1)$ \\
\hline Crop Consumption & $2.8 \mathrm{E}-09(0.3)$ & & & $1.1 \mathrm{E}-07(0.6)$ & $1.1 \mathrm{E}-08 \quad(20)$ \\
\hline Milk Consumption & $1.5 \mathrm{E}-14 \quad(<0.1)$ & & & $5.7 \mathrm{E}-13 \quad(<0.1)$ & $6.0 \mathrm{E}-14 \quad(<0.1)$ \\
\hline Beef Consumption & $1.0 \mathrm{E}-09(0.1)$ & & & $3.8 \mathrm{E}-08 \quad(0.2)$ & $4.1 E-09(7.3)$ \\
\hline Water Consumption & $8.3 E-09(0.9)$ & & & $3.2 \mathrm{E}-07(1.6)$ & $3.6 \mathrm{E}-08 \quad(64)$ \\
\hline Fish Consumption & $8.3 \mathrm{E}-10(<0.1)$ & & & $3.2 \mathrm{E}-08 \quad(0.2)$ & $3.6 \mathrm{E}-09 \quad(6.4)$ \\
\hline Swimming & $7.8 \mathrm{E}-15 \quad(<0.1)$ & $1.2 \mathrm{E}-13 \quad(<0.1)$ & $7.8 \mathrm{E}-15 \quad(<0.1)$ & $7.8 \mathrm{E}-15 \quad(<0.1)$ & $7.8 \mathrm{E}-15 \quad(<0.1)$ \\
\hline Boating & $3.9 \mathrm{E}-15(<0.1)$ & $5.8 \mathrm{E}-14 \quad(<0.1)$ & $3.9 \mathrm{E}-15 \quad(<0.1)$ & $3.9 \mathrm{E}-15 \quad(<0.1)$ & $3.9 \mathrm{E}-15 \quad(<0.1)$ \\
\hline Shoreline Exposure & $8.9 \mathrm{E}-11(<0.1)$ & $8.8 \mathrm{E}-10(85)$ & $8.9 \mathrm{E}-11(<0.1)$ & $8.9 E-11 \quad(<0.1)$ & $8.9 \mathrm{E}-11(0.2)$ \\
\hline Totals & $9.2 \mathrm{E}-07(100)$ & $1.0 E-09(100)$ & $1.6 \mathrm{E}-06(100)$ & $2.0 \mathrm{E}-05(100)$ & $5.6 \mathrm{E}-08(100)$ \\
\hline
\end{tabular}

( ) - percent contribution of pathway to total organ dose. 
APPENDIX B

DOSE FACTORS FOR INHALATION, AND DOSE

CALCULATION RESULTS FOR CLASS W PLUTONIUM 
APPENDIX B

TABLE B.1. Fifty-Year Comnitted Dose Equivalent Factors from Acute Inhalation for Class W Material(a)

\begin{tabular}{|c|c|c|c|c|c|}
\hline \multirow[b]{2}{*}{ Isotope } & \multicolumn{5}{|c|}{ (rem per $\mu \mathrm{g}$ inhaled) } \\
\hline & Total Body & Kidneys & Liver & Bone & Lungs \\
\hline $238 \mathrm{Pu}$ & $1.2 E+3^{(b)}$ & $4.8 E+3$ & $1.5 E+4$ & $2.4 E+4$ & $9.2 E+2$ \\
\hline $239 \mathrm{Pu}$ & $4.6 E+0$ & $1.9 E+1$ & $5.9 E+1$ & $9.7 E+1$ & $3.0 E+0$ \\
\hline $240 \mathrm{Pu}$ & $1.7 E+1$ & $6.9 E+1$ & $2.2 E+2$ & $3.6 E+2$ & $1.1 E+1$ \\
\hline $241 \mathrm{Pu}$ & 1. $3 E+2$ & $6.1 E+2$ & $1.8 E+3$ & $3.2 E+3$ & $1.8 \mathrm{E}+0$ \\
\hline $242 \mathrm{Pu}$ & $2.8 E-1$ & $1.1 E+0$ & $3.6 E+0$ & $5.7 E+0$ & $1.8 \mathrm{E}-1$ \\
\hline $241 \mathrm{Am}$ & $2.0 E+2$ & $1.5 E+3$ & $3.2 E+3$ & $5.2 E+3$ & $1.7 E+2$ \\
\hline
\end{tabular}

(a)Committed dose equivalent factors calculated using DACRIN for $1 \mu \mathrm{m}$ AMAD size particles. Organ masses are those reported in ICRP-23. (b) $1.2 E+3$ is identical to $1.2 \times 10^{3}$.

TABLE B.2. Fifty-Year Committed Dose Equivalent Factors from Acute Inhalation for Class Y Material

\begin{tabular}{|c|c|c|c|c|c|}
\hline \multirow[b]{2}{*}{ Isotope } & \multicolumn{5}{|c|}{ (rem per $\mu \mathrm{g}$ inhaled) } \\
\hline & Total Body & Kidneys & Liver & Bone & Lungs \\
\hline $238 \mathrm{Pu}$ & $4.3 E+2$ & $1.8 E+3$ & $5.8 E+3$ & $8.9 E+3$ & $9.0 E+3$ \\
\hline $239 \mathrm{Pu}$ & $1.7 E+0$ & $7.1 E+0$ & $2.3 E+1$ & $3.7 E+1$ & $3.0 E+1$ \\
\hline $240 \mathrm{Pu}$ & $6.3 E+0$ & $2.6 \mathrm{E}+1$ & $8.3 E+1$ & $1.3 E+2$ & $1.1 E+2$ \\
\hline $241 \mathrm{Pu}$ & $4.3 E+1$ & $2.0 E+2$ & $6.0 \mathrm{E}+2$ & $1.1 E+3$ & $9.6 E+1$ \\
\hline $242 \mathrm{Pu}$ & $1.0 E-1$ & $4.3 E-1$ & $1.4 \mathrm{E}+0$ & $2.2 E+0$ & $1.8 E+0$ \\
\hline $241 \mathrm{Am}$ & $7.8 E+1$ & $5.6 \mathrm{E}+2$ & $1.2 E+3$ & $1.9 E+3$ & $1.7 E+3$ \\
\hline
\end{tabular}


TABLE B.3. Fifty-Year Committed Dose Equivalent Factors from One-Year Chronic Inhalation for Class W Material

\begin{tabular}{|c|c|c|c|c|c|}
\hline \multirow{2}{*}{ Isotope } & \multicolumn{5}{|c|}{ (rem per $\mu \mathrm{g}$ inhaled in first year) } \\
\hline & Total Body & Kidneys & Liver & Bone & Lungs \\
\hline $238 \mathrm{Pu}$ & $1.2 \mathrm{E}+3$ & $4.8 \mathrm{E}+3$ & $1.5 E+4$ & $2.4 E+4$ & $9.2 E+2$ \\
\hline $239 \mathrm{Pu}$ & $4.5 E+0$ & $1.9 E+1$ & $5.8 E+1$ & $9.7 E+1$ & $3.0 E+0$ \\
\hline $240 \mathrm{Pu}$ & $1.7 E+1$ & $6.8 E+1$ & $2.2 E+2$ & $3.6 \mathrm{E}+2$ & $1.1 E+1$ \\
\hline $241 \mathrm{Pu}$ & $1.3 E+2$ & $6.1 E+2$ & $1.8 E+3$ & $3.2 E+3$ & $1.8 \mathrm{E}+0$ \\
\hline 242Pu & $2.8 \mathrm{E}-1$ & $1.1 E+0$ & $3.6 E+0$ & $5.7 \mathrm{E}+0$ & $1.8 \mathrm{E}-1$ \\
\hline $241 \mathrm{Am}$ & $2.0 E+2$ & $1.5 E+3$ & $3.2 E+3$ & $5.1 E+3$ & $1.7 E+2$ \\
\hline
\end{tabular}

TABLE B.4. Fifty-Year Committed Dose Equivalent Factors from One-Year Chronic Inhalation for Class Y Material

\begin{tabular}{|c|c|c|c|c|c|}
\hline \multirow[b]{2}{*}{ Isotope } & \multicolumn{5}{|c|}{ (rem per $\mu \mathrm{g}$ inhaled in first year) } \\
\hline & Tota 7 Body & Kidneys & Liver & Bone & Lungs \\
\hline $238 \mathrm{Pu}$ & $4.3 E+2$ & $1.8 \mathrm{E}+3$ & $5.7 E+3$ & $8.8 E+3$ & $9.0 E+3$ \\
\hline${ }^{239} \mathrm{Pu}$ & $1.7 E+0$ & $7.0 E+0$ & $2.2 E+1$ & $3.6 E+1$ & $3.0 E+1$ \\
\hline${ }^{240} \mathrm{Pu}$ & $6.2 E+0$ & $2.6 \mathrm{E}+1$ & $8.2 E+1$ & 1. $3 E+2$ & 1. $1 E+2$ \\
\hline${ }^{24} \mathrm{Pu}$ & $4.3 E+1$ & $2.0 E+2$ & $6.0 E+2$ & $1.0 E+3$ & $9.6 \mathrm{E}+1$ \\
\hline${ }^{242} \mathrm{Pu}$ & $1.0 \mathrm{E}-1$ & $4.3 E-1$ & $1.4 \mathrm{E}+0$ & $2.1 E+0$ & $1.8 \mathrm{E}+0$ \\
\hline${ }^{241} \mathrm{Am}$ & $7.7 E+1$ & $5.6 \mathrm{E}+2$ & $1.2 E+3$ & $1.9 \mathrm{E}+3$ & $1.7 E+3$ \\
\hline
\end{tabular}

TABLE B.5. Fifty-Year Committed Dose Equivalents from Inhalation Following Earthquake No. 2 (Class W)

\begin{tabular}{|c|c|c|c|c|c|c|c|c|}
\hline \multirow[b]{2}{*}{$\begin{array}{r}\text { Organ of } \\
\text { Reference }\end{array}$} & \multicolumn{8}{|c|}{ Committed Dose Equivalents for: } \\
\hline & $\begin{array}{r}\text { Po } \\
\text { Case I(b) }\end{array}$ & $\frac{\text { dlation }}{\text { Case II }}$ & $\begin{array}{l}\text { gerson-rem } \\
\text { Case III }\end{array}$ & $\overline{C a s e ~ I V ~}$ & $\frac{\mathrm{Ne}}{\mathrm{Case} \mathrm{I}}$ & $\frac{\text { rest Resi }}{\text { Case II }}$ & $\frac{\operatorname{dence}(a)}{\text { Case III }}$ & $\frac{(\text { rem) }}{\text { Case IV }}$ \\
\hline Total Body & $8.4 \mathrm{E}-3$ & $5.4 \mathrm{E}-2$ & $3.0 \mathrm{E}-2$ & $2.2 \mathrm{E}-1$ & $1.9 E-5$ & $1.7 \mathrm{E}-4$ & $6.9 E-5$ & $4.6 E-4$ \\
\hline Kidneys & $3.7 E-2$ & $2.4 E-1$ & $1.3 \mathrm{E}-1$ & $9.8 \mathrm{E}-1$ & $8.5 E-5$ & $5.0 E-4$ & 3. IE-4 & $2.0 E-3$ \\
\hline Liver & 1. $1 E-1$ & $7.2 E-1$ & 4. $1 E-1$ & $3.0 \mathrm{E}+0$ & $2.6 E-4$ & $1.5 E-3$ & $9.3 E-4$ & $6.2 E-3$ \\
\hline Bone & $1.9 \mathrm{E}-1$ & $1.2 E+0$ & $6.8 \mathrm{E}-1$ & 4. $9 E+0$ & $4.3 E-4$ & $2.5 E-3$ & $1.5 \mathrm{E}-3$ & 1. $0 \mathrm{E}-2$ \\
\hline Lungs & $4.2 E-3$ & $2.7 E-2$ & $1.5 E-2$ & $1.1 \mathrm{E}-1$ & $9.7 \mathrm{E}-6$ & $5.7 \mathrm{E}-5$ & $3.5 \mathrm{E}-5$ & 2. $3 E-4$ \\
\hline
\end{tabular}

(a) Located 150 meters NE of the plant.

(b) Case I - most likely release with most likely dispersion; Case II - most likely release with conservative dispersion; Case III - conservative release with most likely dispersion; Case IV - conservative release with conservative dispersion. 
TABLE B.6. Fifty-Year Committed Dose Equivalents from Inhalation Following Earthquake No. 3 (Class W)

\begin{tabular}{|c|c|c|c|c|c|c|c|c|}
\hline \multirow{3}{*}{$\begin{array}{r}\text { Organ of } \\
\text { Reference }\end{array}$} & \multicolumn{8}{|c|}{ Committed Dose Equivalents for: } \\
\hline & \multicolumn{2}{|c|}{ Population } & \multicolumn{2}{|c|}{ (person-rem) } & \multicolumn{3}{|c|}{ Nearest Residence(a) } & \multirow{2}{*}{$\frac{(\text { rem })}{\text { Case IV }}$} \\
\hline & Case I & Case II & Case III & Case IV & Case I & Case II & Case III & \\
\hline Total Body & $2.0 E+3$ & $1.2 E+4$ & $4.0 E+4$ & $1.9 E+5$ & $4.7 \mathrm{E}+0$ & $2.6 E+1$ & $9.3 E+1$ & $4.2 E+2$ \\
\hline Kidneys & $9.0 E+3$ & $5.4 E+4$ & $1.8 E+5$ & $8.3 E+5$ & $2.1 E+1$ & $1.1 E+2$ & $4.1 E+2$ & $1.8 E+3$ \\
\hline Liver & $2.7 \mathrm{E}+4$ & $1.6 E+5$ & $5.4 E+5$ & $2.5 \mathrm{E}+6$ & $6.3 E+1$ & $3.5 E+2$ & $1.2 E+3$ & $5.6 E+3$ \\
\hline Bone & $4.6 \mathrm{E}+4$ & $2.7 E+5$ & $9.0 \mathrm{E}+5$ & $4.2 E+6$ & $1.0 \mathrm{E}+2$ & $5.8 E+2$ & $2.1 E+3$ & $9.3 E+3$ \\
\hline Lungs & 1. $.0 E+3$ & $6.1 E+3$ & $2.0 E+4$ & $9.4 E+4$ & 2. $3 E+0$ & $1.3 E+1$ & $4.6 \mathrm{E}+1$ & $2.1 E+2$ \\
\hline
\end{tabular}

(a)Located 150 meters NE of the plant.

TABLE B.7. Fifty-Year Committed Dose Equivalents from Inhalation Following 85-mph and 95-mph Straight-Line Winds (Class W)

\begin{tabular}{|c|c|c|c|c|c|c|c|c|}
\hline \multirow{3}{*}{$\begin{array}{l}\text { Organ of } \\
\text { Reference }\end{array}$} & \multicolumn{8}{|c|}{ Committed Dose Equivalents for: } \\
\hline & \multicolumn{2}{|c|}{ Population } & \multicolumn{2}{|c|}{ (person-rem) } & \multicolumn{4}{|c|}{ Nearest Residence (a) $(\mathrm{rem})$} \\
\hline & Case & Case II & Case III & Case IV & Case I & Case II & Case III & Case IV \\
\hline Total Body & $7.2 \mathrm{E}+1$ & $2.9 E+2$ & $5.7 E+2$ & $2.3 E+3$ & $1.7 E=1$ & $6.5 \mathrm{E}-1$ & $1.3 \mathrm{E}+0$ & $5.2 \mathrm{E}+0$ \\
\hline Kidneys & $3.2 E+2$ & $1.3 E+3$ & $2.5 E+3$ & $1.0 E+4$ & $7.3 E-1$ & $2.9 \mathrm{E}+0$ & $5.8 \mathrm{E}+0$ & 2. $3 E+1$ \\
\hline Liver & $9.6 \mathrm{E}+2$ & $3.8 E+3$ & $7.6 E+3$ & $3.0 \mathrm{E}+4$ & $2.2 E+0$ & $8.8 \mathrm{E}+0$ & $1.8 E+1$ & $6.9 E+1$ \\
\hline one & $1.6 E+3$ & $6.4 E+3$ & $1.3 E+4$ & $5.1 E+4$ & $3.7 E+0$ & $1.5 E+1$ & 2. $9 E+1$ & $1.2 E+2$ \\
\hline Lungs & $3.6 E+1$ & $1.4 E+2$ & $2.8 \mathrm{E}+2$ & $1.1 E+3$ & $8.3 E-2$ & $3.3 E-1$ & $6.6 \mathrm{E}-1$ & $2.6 E+0$ \\
\hline
\end{tabular}

(a)Located 150 meters NE of the plant. 
TABLE B.8. Fifty-Year Committed Dose Equivalents from Inhalation Following 110-mph and 130-mph Straight-Line Winds (Class W)

\begin{tabular}{|c|c|c|c|c|c|c|c|c|}
\hline \multirow{3}{*}{$\begin{array}{l}\text { Organ of } \\
\text { Reference }\end{array}$} & \multicolumn{8}{|c|}{ Committed Dose Equivalents for: } \\
\hline & \multicolumn{2}{|c|}{ Population } & \multicolumn{2}{|c|}{ (person-rem) } & \multicolumn{4}{|c|}{ Nearest Residence $(a)($ rem $)$} \\
\hline & Case & Case II & Case III & Case IV & Case I & Case I I & Case III & Case IV \\
\hline Total Body & $1.4 \mathrm{E}+3$ & $5.6 \mathrm{E}+3$ & $3.6 \mathrm{E}+4$ & $1.4 \mathrm{E}+5$ & $3.2 E+0$ & $1.3 E+1$ & $8.3 \mathrm{E}+1$ & $3.3 E+2$ \\
\hline Kidneys & $6.2 E+3$ & $2.5 \mathrm{E}+4$ & $1.6 \mathrm{E}+5$ & $6.4 \mathrm{E}+5$ & $1.4 \mathrm{E}+1$ & $5.7 \mathrm{E}+1$ & $3.7 E+2$ & $1.5 E+3$ \\
\hline Liver & $1.9 \mathrm{E}+4$ & $7.5 E+4$ & $4.8 \mathrm{E}+5$ & $1.9 \mathrm{E}+6$ & $4.3 E+1$ & $1.7 \mathrm{E}+2$ & $1.1 E+3$ & $4.4 E+3$ \\
\hline Bone & $3.1 E+4$ & $1.3 \mathrm{E}+5$ & $8.1 E+5$ & $3.2 E+6$ & $7.2 E+1$ & $2.9 E+2$ & $1.9 E+3$ & $7.4 E+3$ \\
\hline Lungs & $7.0 E+2$ & $2.8 \mathrm{E}+3$ & $1.8 \mathrm{E}+4$ & $7.2 E+4$ & $1.6 \mathrm{E}+0$ & $6.4 \mathrm{E}+0$ & $4.2 E+1$ & $1.7 \varepsilon+2$ \\
\hline
\end{tabular}

(a) Located 150 meters NE of the plant.

TABLE B.9. Fifty-Year Committed Dose Equivalents from Inhalation Following a 130-mph Tornado (Class W)

Committed Dose Equivalents for:

\begin{tabular}{|c|c|c|c|c|c|c|c|c|}
\hline & & & \\
\hline \multirow{2}{*}{$\begin{array}{r}\text { Organ of } \\
\text { Reference } \\
\end{array}$} & \multirow{2}{*}{\multicolumn{4}{|c|}{ Population (person-rem) }} & \multicolumn{4}{|c|}{ Nearest Residence $(a)(r e m)$} \\
\hline & Case I & Case II & Case III & & Case I & Case II & Case III & Case IV \\
\hline Total Body & $1.5 E+3$ & $6.1 E+3$ & $3.6 \mathrm{E}+4$ & $1.5 \mathrm{E}+5$ & $3.2 E+0$ & 1. $3 \mathrm{E}+1$ & $8.3 E+1$ & $3.3 \mathrm{E}+2$ \\
\hline Kidneys & $6.4 \mathrm{E}+3$ & $2.7 E+4$ & $1.6 \mathrm{E}+5$ & $6.5 \mathrm{E}+5$ & $1.4 \mathrm{E}+1$ & $5.7 \mathrm{E}+1$ & $3.7 E+2$ & $1.5 E+3$ \\
\hline Liver & $1.9 \mathrm{E}+4$ & $8.2 E+4$ & $4.9 E+5$ & $2.0 \mathrm{E}+6$ & $4.3 E+1$ & 1. $7 E+2$ & $1.1 \mathrm{E}+3$ & $4.4 \mathrm{E}+3$ \\
\hline Bone & $3.2 E+4$ & $1.4 E+5$ & $8.1 E+5$ & $3.3 \mathrm{E}+6$ & $7.2 E+1$ & $2.9 E+2$ & $1.9 \mathrm{E}+3$ & $7.4 E+3$ \\
\hline Lungs & $7.3 \mathrm{E}+2$ & $3.0 E+3$ & $1.8 \mathrm{E}+4$ & $7.4 \mathrm{E}+4$ & $1.6 \mathrm{E}+0$ & $6.4 \mathrm{E}+0$ & $4.2 E+1$ & $1.7 E+2$ \\
\hline
\end{tabular}

(a)Located 150 meters NE of the plant. 


\section{REFERENCES}

Anspaugh, L. R. 1976. "Appendix A, Resuspension Element Status Report: The Use of NTS Data and Experience to Predict Air Concentrations of Plutonium Due to Resuspension on the Eniwetok Atoll." In Nevada Applied Ecology Group Procedures Handbook for Environmental Transuranics. Vol. 2. NV0-166, Energy Research and Development Administration, Las Vegas, NV.

Anspaugh, L. R., J. H. Shinn, P. L. Phelps and N. C. Kennedy. 1975. "Resuspension and Redistribution of Plutonium in Soils," Health Phys. 29(4):571-582.

Baker, D. A. 1977. User Guide for Computer Program FO0D. BNWL-2209, Pacific Northwest Laboratory, Richland, WA 99352.

Baker, D. A., G. R. Hoenes and J. K. Soldat. 1966. FO0D - An Interactive Code to Calculate Internal Radiation Doses from Contaminated Food Products. BNWL-SA-5523, Battelle, Pacific Northwest Laboratories, Richland, WA.

Bennett, B. G. 1975. "Transuranic Element Pathways to Man." In Transuranic Nuclides in the Environment, IAEA-SM-199/40, International Atomic Energy Agency, San Francisco, CA.

Cohen, B. L. 1977. "Hazards from Plutonium Toxicity." Health Phys. 32(5): $370-371$.

Dunster, H. J. 1962. "Surface Contamination Measurements as an Index of Control of Radioactive Materials." Health Phys. 8(4):354.

Environmental Protection Agency. 1977. Proposed Guidance on Dose Limits for Persons Exposed to Transuranium Elements in the General Environment. EPA 520/477-016.

Final Environmental Statement by Fuels and Materials Directorate of Licensing U.S. Atomic Energy Commission Related to the Exxon Nuclear Company Mixed Fabrication Plant. 1974. Section V, Docket No. 70-1257.

Friedman, Arnold M., ed. 1976. Actinides in the Environment. American Chemical Society Symposium Series 35. American Chemical Society, Washington, DC.

Fujita, T. T. 1977. Review of Severe Weather Meteorology at Babcock and Wilcox Company, Leechburg, Pennsylvania. ANL Contract No. 31-109-38-3731, University of Chicago, Chicago, IL.

Gudiksen, P. H., K. R. Peterson, R. Lange and J. B. Knox. 1976. "Plume Depletion Following Postulated Atmospheric Plutonium Dioxide Releases." Health Phys. 31(2):127-133. 
Guthrie, C. E., and J. P. Nichols. 1964. Theoretical Possibilities and Consequences of Major Accidents in $233 \mathrm{U}$ and $239 \overline{P U}$ Fuel Fabrication and Radioisotope Processing Plants. ORNL-3441, Oak Ridge Nationa T Laboratory, Oak Ridge, TN 37380 .

Hanson, W. C. 1975. "Ecological Considerations of the Behavior of Plutonium in the Environment." Health Phys. 28(5):532.

Hazle, A. J., and B. L. Crist. 1975. Colorado's Plutonium In-Soil Standard. Colorado Department of Health, Occupational and Radiological Health Division, Denver, CO.

Healy, J. W. 1974. A Proposed Interim Standard for Plutonium in Soils. LA-5483-MS, Los Alamos Scientific Laboratory, LoS ATamos, NM.

Healy, J. W. 1977. An Examination of the Pathways from Soil to Man for Plutonium. LA-6741-MS, Los ATamos Scientific Laboratory, Los ATamos, NM.

Hoenes, G. R., and J. K. Soldat. 1977. Age-Specific Radiation Dose Commitment Factors for a One-Year Chronic Intake. NUREG-0172, U.S. Nuclear ReguTatory Commission Report Prepared by BattelTe, Pacific Northwest Laboratory, Richland, WA.

Hoffman, F. 0., General Chairman. 1978. Proceedings of a Workshop on the Evaluation of Models Used for the Environmental Assessment of Radionuclide Releases, CONF-770901, Oak Ridge National Laboratory, Oak Ridge, TN.

Houston, J. R., D. L. Strenge and E. C. Watson. 1974. DACRIN - A Computer Program for Calculating Organ Dose from Acute or Chronic Inhalation. BNWLB-389, BNWL-B-287, SUPP, Feburary 1975, Pacific Northwest Laboratory, Richland, WA 99352.

International Commission on Radiological Protection (ICRP). 1959. Report of Committee I I on Permissible Dose for Internal Radiation. Publication 2, Pergamon Press, Oxford.

International Commission on Radiological Protection (ICRP). 1972. The Metabolism of Compounds of Plutonium and Other Actinides. Publication 19, Pergamon Press, 0xford.

International Commission on Radiological Protection (ICRP). 1975. Report of the Task Group on Reference Man. Report 23, Pergamon Press, Oxford.

Kathren, R. L. 1968. Towards Interim Acceptable Surface Contamination Levels for Environmental $\mathrm{PuO}_{2}$. BNWL-SA-1510, Pacific Northwest Laboratory, Richland, WA 99352. 
Klement, A. W., Jr. 1972. Estimates of Ionizing Radiation Doses in the United States 1960-2000. ORP/CDS 72-1, Environmental Protection Agency.

Martin, W. E., and S. C. Bloom. 1975. Plutonium Transport and Dose Estimation Mode1. IAEA-SM-199/78, International Atomic Energy Agency, San Francisco, CA.

Mishima, J., L. C. Schwendiman, and J. E. Ayer. 1978. An Estimate of Airborne Release of Plutonium from Babcock and Wilcox Plant as a Result of Severe Wind Hazard and Earthquake. PNL-2812, Pacific Northwest Laboratory, Richland, WA.

Nuclear Regulatory Commission (NRC). 1978. Environmental Impact Appraisal of the Babcock and Wilcox Company (B\&W) Nuclear Materials Division, Leechburg, Parks Township, Pennsylvania. Washington, DC 20555.

Pepper, D. W. 1978. Calculation of Particulate Dispersion in a Design-Bas is Tornadic Storm from the Babcock and Wilcox Plant, Leechburg, Pennsylvania. DP-1487, E. I. Dupont de Nemours and Company, Savannah River Laboratory, Aiken, SC.

Sehme1, G. A. 1977. Transuranic and Tracer Simulant Resuspension. BNWL-SA6236. Pacific Northwest Laboratory, Richland, WA 99352.

Selby, J. M., et al. 1975. Considerations in the Assessment of the Consequences of Effluents from Mixed Oxide Fuel Fabrication Plants. BNWL-1967, Rev. 1, Pacific Northwest Laboratory, Richland, WA 99352.

Soldat, J. K., N. M. Robinson and D. A. Baker. 1974. Models and Computer Codes for Evaluating Environmental Radiation Doses. BNWL-1754, Battelle, Pacific Northwest Laboratories, Richland, WA. (Table BIOACl updated by Soldat December 1977.)

Task Group on Lung Dynamics for Committee 2 of the International Commission on Radiological Protection. 1966. "Deposition and Retention Models for Internal Dosimetry of the Human Respiratory Tract." Health Phys. 12(2):173-207.

USNRC Regulatory Guide 1.109. 1977. Calculation of Annual Doses to Man from Routine Releases of Reactor Effluents for the Purpose of Evaluating Compliance with 10 CFR Part 50, Appendix I. Rev. T.

USNRC Regulatory Guide 1.111. 1977. Methods for Estimating Atmospheric Transport and Dispersion of Gaseous Effluents in Routine Releases from Light-WaterCooled Reactors. Rev. 1. 
United Nations Scientific Committee on Effects of Atomic Radiation. 1977. Sources and Effects of Ionizing Radiation. New York.

U.S. Code. 1976. Title 49, part 173, "Shippers - General Requirements for Shipments and Packaging." Superintendent of Documents, U.S. Government Printing Office, Washington, DC 20402.

Wahlgren, M.A., and J. S. Marshal1. 1975. The Behavior of Plutonium and Other Long-Lived Radionuclides in Lake Michigan: I. Biological Transport, Seasonal Cycling, and Residence Times in the Water Column. IAEA-SM-198/39, Argonne National Laboratory, Argonne, IL. 
$P N L-2833$

$U C-20 \mathrm{e}$

\section{DISTRIBUTION LIST}

No. of

Copies

OFFSITE

A. A. Churm DOE Patent Division $9800 \mathrm{~S}$. Cass Avenue Argonne, IL 60439

25

U.S. Nuclear Regulatory Commission

Division of Technical Information \& Document Control

7920 Norfolk Avenue

Bethesda, MD 20014

27 DOE Technical Information Center

10 J. E. Ayer

U.S. Nuclear Regulatory Commission

Washingtor, DC 20555

W. Burkhardt

U.S. Nuclear Regulatory Commission

Washington, DC 20555

J. W. Johnson

U.S. Nuclear Regulatory Commission

Washington, DC 20555

W. E. Vesely

U.S. Nuclear Regulatory Commission Washington, DC 20555

J. E. Carson

Argonne National Laboratory 9800 S. Cass Avenue

Argonne, IL 60439
No. of

Copies

D. W. Pepper

Savannah River Laboratory

E. I. duPont de Nemours \& Co.

Aiken, SC 29801

T. T. Fujita

Dept. of Geophysical Sciences

University of Chicago

Chicago, IL 60637

R. F. Abbey

U.S. Nuclear Regulatory Commission Washington, DC 20555

R. P. Kennedy

Engineering Decision Analys is Company 2400 Michelson Drive

Irvine, CA 92715

J. R. McDonald

Texas Tech University

Institute for Disaster Research

P.0. Box 4089

Lubbock, TX 79409

K. C. Mehta

Texas Tech University

Institute for Disaster Research

P.0. Box 4089

Lubbock, TX 79409

ONSITE

DOE Richland Operations Office

H. E. Ransom 
ONSITE

26 Pacific Northwest Laboratory

D. A. Baker

N. M. Burleigh

R. J. Ha11

J. Mishima

L. C. Schwendiman

R. B. McPherson (10)

J. K. Soldat

D. L. Strenge

E. C. Watson

L. D. Williams

Technical Information (5)

Publishing Coordination (2)

Mà 